\title{
Comprehensive genetic dissection of wood properties in a widely-grown tropical tree: Eucalyptus
}

Jean-Marc Gion ${ }^{1,8^{*}}$, Audrey Carouché ${ }^{1}$, Sylvie Deweer ${ }^{1}$, Franck Bedon ${ }^{1}$, Frédérique Pichavant ${ }^{2}$, Jean-Paul Charpentier ${ }^{3}$, Henri Baillères ${ }^{4}$, Philippe Rozenberg ${ }^{3}$, Victor Carocha ${ }^{5}$, Nina Ognouabi ${ }^{6}$, Daniel Verhaegen ${ }^{1}$, Jacqueline Grima-Pettenati', Philippe Vigneron ${ }^{1,6}$ and Christophe Plomion ${ }^{8}$

\begin{abstract}
Background: Eucalyptus is an important genus in industrial plantations throughout the world and is grown for use as timber, pulp, paper and charcoal. Several breeding programmes have been launched worldwide to concomitantly improve growth performance and wood properties (WPs). In this study, an interspecific cross between Eucalyptus urophylla and E. grandis was used to identify major genomic regions (Quantitative Trait Loci, QTL) controlling the variability of WPS.

Results: Linkage maps were generated for both parent species. A total of 117 QTLs were detected for a series of wood and end-use related traits, including chemical, technological, physical, mechanical and anatomical properties. The QTLs were mainly clustered into five linkage groups. In terms of distribution of QTL effects, our result agrees with the typical L-shape reported in most QTL studies, i.e. most WP QTLs had limited effects and only a few (13) had major effects (phenotypic variance explained > 15\%). The co-locations of QTLs for different WPs as well as QTLs and candidate genes are discussed in terms of phenotypic correlations between traits, and of the function of the candidate genes. The major wood property QTL harbours a gene encoding a Cinnamoyl CoA reductase (CCR), a structural enzyme of the monolignol-specific biosynthesis pathway.
\end{abstract}

Conclusions: Given the number of traits analysed, this study provides a comprehensive understanding of the genetic architecture of wood properties in this Eucalyptus full-sib pedigree. At the dawn of Eucalyptus genome sequence, it will provide a framework to identify the nature of genes underlying these important quantitative traits.

Keywords: Wood properties, QTL, genetic mapping, candidate genes, Eucalyptus

\section{Background}

Eucalyptus is the main hardwood genus used in intensively managed forest tree plantations. Because of its high productivity on marginal sites, high fibre content and usefulness in producing a wide range of forest products, Eucalyptus has been widely planted in subtropical, tropical and temperate regions of the world, accounting for $8 \%$ of the planted forest area [1]. Intensive silvicultural practices and traditional genetic

\footnotetext{
* Correspondence: gion@cirad.fr

'CIRAD, Department of Biological System, Research Unit "Genetic improvement and adaptation of mediterranean and tropical plants" TA A108/C, Campus International de Baillarguet, 34398 Montpellier Cedex, France Full list of author information is available at the end of the article
}

improvement have both contributed to improve the productivity of wood biomass [2]. Wood properties (WPs) have also become mandatory traits in breeding programmes for the development of improved varieties for pulp and paper, energy wood or timber production.

WPs vary greatly between species, within species and within a tree (reviewed by Plomion et al. [3]) and change with age (reviewed by Raymond [4]). They can be classified in five categories: i) mechanical properties in response to applied forces (e.g. longitudinal growth strain, modulus of elasticity, strength), ii) technological characteristics, which are the consequences of the mechanical state of the tree (e.g. splitting index), iii) physical characteristics, corresponding to the natural 
characteristics of wood which affect mechanical properties (e.g. wood density, shrinkage), iv) anatomical characteristics (e.g. fibre length, fibre thickness, coarseness), and v) traits related to chemical composition (e.g. cellulose and lignin content, lignin composition). A key constraint to higher-value uses of some Eucalyptus species used for timber production is their high internal stresses in the stem [5-7]. The release of growth stresses during cross-cutting may cause radial cracks at the log end. This "end-splitting" phenomenon increases with time according to an asymptotic curve. The extent of this degrade can be explained by the high level of growth stresses, low wood transverse strength and gradients of mechanical properties [8]. Previous studies indicated that growth stresses were not correlated with growth or other WPs [9-11]. The chemical composition (cellulose, hemi-celluloses, lignins, flavonoids, tannins, etc.) of wood also greatly influences the properties and performance of pulp, paper and charcoal. Different authors reported strong correlations between pulp yield and cellulose content in E. urophylla [12] or lignin content in E. globulus [13]. Another study suggested that the lower kraft pulp yield of E. viminalis can, to a large extent, be attributed to the higher soluble and insoluble tannin contents of the wood [14]. Interestingly, lignin content has been reported to be negatively correlated with longitudinal growth strain in Eucalyptus hybrids [8], suggesting a relationship between micro (chemical composition) and macro (mechanical properties) characteristics of wood.

The genetic determinism of WPs has been fairly well studied in Eucalyptus [4]. In E. globulus, Apiolaza et al. [15] reported moderate to high heritability for several WPs without any significant genetic correlation with growth, except between microfibril angle and trunk diameter (-0.86). In E. grandis, no significant correlation was found between wood density and growth [16]. In $E$. urophylla, a narrow sense heritability of 0.5 was estimated for cellulose content with no correlation with growth [12]. Silva et al. [17] found a significant genetic correlation between wood density (a highly heritable trait) and growth diameter in E. globulus. Other authors reported a significant correlation between WPs, e.g. microfibril angle and basic density $(-0.70)$ and pulp yield and cellulose content (0.82) [15]. Together, these results suggest: i) a higher heritability for WPs than growthrelated traits, ii) some form of pleiotropic relationships between different WPs or close linkage between the genes controlling these traits, and iii) an inconsistency regarding the extent of genetic correlations between WPs and growth. Despite attempts to describe the number, location, effects and nature of the genes underlying these quantitative traits, up to now, very little effort has been made toward a more comprehensive analysis of the genetic architecture of WPs taking into account in a single experiment mechanical, physical, technological, anatomical and chemical properties.

Investigating the genetic basis of multi-scale WPs has become a major issue while the sequence of the Eucalyptus genome is nearing completion $[2,18]$. Dissecting the genetic architecture of such complex traits can be addressed by QTL mapping [19]. In Eucalyptus, several QTL studies have focused on wood density [20-22]. Barros et al. [23] identified molecular markers linked to wood splitting in open-pollinated E. grandis. Thamarus et al. [24] published the first significant results on the genetic architecture of WPs using high throughput phenotyping methods to detect QTLs for fibre length, cellulose, pulp yield and microfibril angle (MFA) in E. globulus. Three QTLs (wood-fibre, wood density and pulp yield) were detected across two half-sib pedigrees indicating a stable effect of the genetic control across different genetic backgrounds. Rocha et al. [25] found co-located QTLs for pulp yield and lignin content in an interspecific cross E. grandis $\times$ E. urophylla. Similar linkages were reported between pulp yield and cellulose content in E. globulus [24]. More recently, Freeman et al. [26] discovered several genomic regions of E. globulus affecting physical (density) and chemical wood properties, e.g. co-located QTLs for lignin content, cellulose content and pulp yield. Finally, Thumma et al. [27] identified QTLs for density, MFA and wood chemical components in E. nitens.

The availability of Eucalyptus sequences in public databases (reviewed in Myburg et al. [28]) makes it possible to propose functional candidate genes a priori involved in the genetic control of the traits concerned, e.g. structural and regulatory genes involved in lignification for traits related to lignin content and lignin quality. Differentiating secondary xylem libraries [29] and high-throughput transcriptome sequencing [30] are also useful sources of functional molecular markers to decipher the nature of QTLs for WPs. Some co-locations between QTLs for wood quality related traits and functional candidate genes have already been reported: e.g. between a transcription factor (EgMYB2) and a QTL for lignin content in E. grandis [31], between a vascular-expressed Rac-like small GTPase (EgROP1) and lignin composition and fibre morphology in E. urophylla [32], between the gene encoding a cinnamoyl-CoA reductase (CCR) and a QTL for cellulose content in $E$. globulus [24], and between CCR and a QTL for MFA in E. nitens [27].

In this context, the objectives of this study were twofold: i) to perform an extensive QTL analysis for a large range of WPs in an interspecific cross of Eucalyptus in order to dissect the genetic architecture of these complex multi-scale traits, ii) to identify positional candidate 
genes co-locating with WP-QTLs, as the basis of future positional cloning of major QTLs.

\section{Methods}

Genetic material and DNA extraction

An interspecific hybrid progeny (F1 outbreed) of E. urophylla and E. grandis was used to dissect wood properties into their Mendelian inherited components (QTLs). This progeny was also used by Verhaegen and Plomion [33], Verhaegen et al. [21] and Gion et al. [34] in previous linkage and QTL mapping studies. A total of 201 full-sibs planted in 1992 were felled at 59 months old. Genomic DNA was extracted from dried leaves according to Doyle and Doyle [35] with minor modifications described by Verhaegen and Plomion [33].

\section{Phenotypic assessment}

Total height (Ht59) and trunk circumference at $1.3 \mathrm{~m}$ (Cir59) were measured once the trees were cut down at 59 months old. Three logs were cut from each tree, corresponding to a butt $\log$ ( $2.5 \mathrm{~m}$ in length), an intermediate $\log (1.5 \mathrm{~m}$ in length) taken at half the commercial height (i.e. height measured at $8 \mathrm{~cm}$ diameter), and a third $\log$ (1.5 $\mathrm{m}$ in length) sampled at three-quarters of the commercial height. WPs were measured at different levels as shown in Figure 1.

\section{Chemical properties}

A 7-cm disk was sampled in the middle of the intermediate log and crushed into wood powder (40 mesh). Four types of traits were measured: i) lignin content, ii) lignin composition, iii) polyphenol, and iv) flavanol contents. Klason lignin was measured according to Tappi T222 om-83 and the modified procedure of Effland [36]. Lignin monomers were characterized by thioacidolysis, an efficient procedure to estimate the amount of Syringyl (S), Guaiacyl (G) and Hydroxyphenyl (H) units [37]. Total polyphenols (Poly) and flavanols (flavan-3-ols and condensed tannins, Fla) were measured using $50 \mathrm{mg}$ of Eucalyptus dry wood meal, after two successive extractions with $2 \mathrm{~mL}$ of $80 \%$ methanol. The mixture was sonicated for $30 \mathrm{~min}$ before being centrifuged at 18,000 g for $10 \mathrm{~min}$. Supernatants from both extractions were pooled. All the steps were carried out at $4^{\circ} \mathrm{C}$. For Poly quantification, $500 \mu \mathrm{L}$ of supernatants were dried under vacuum using a "Speed-Vac" system (Savant Instrument) and suspended in $500 \mu \mathrm{L}$ ultra-pure water. Poly content was estimated by colorimetric assay based on oxidationreduction reactions with Folin-Ciocalteu reagent $[38,39]$. $100 \mu \mathrm{L}$ of phenolic extract, $500 \mu \mathrm{L}$ of Folin-Ciocalteu reagent (Sigma, diluted 10 times in ultra-pure water) and $400 \mu \mathrm{L}$ of $\mathrm{NaCO}_{3} 75$ g. $\mathrm{L}^{-1}$ were successively mixed and incubated for $5 \mathrm{~min}$ at $40^{\circ} \mathrm{C}$. Absorbance at $735 \mathrm{~nm}$ was measured spectrophotometrically and the results expressed in mg equivalent of Gallic acid per gram of

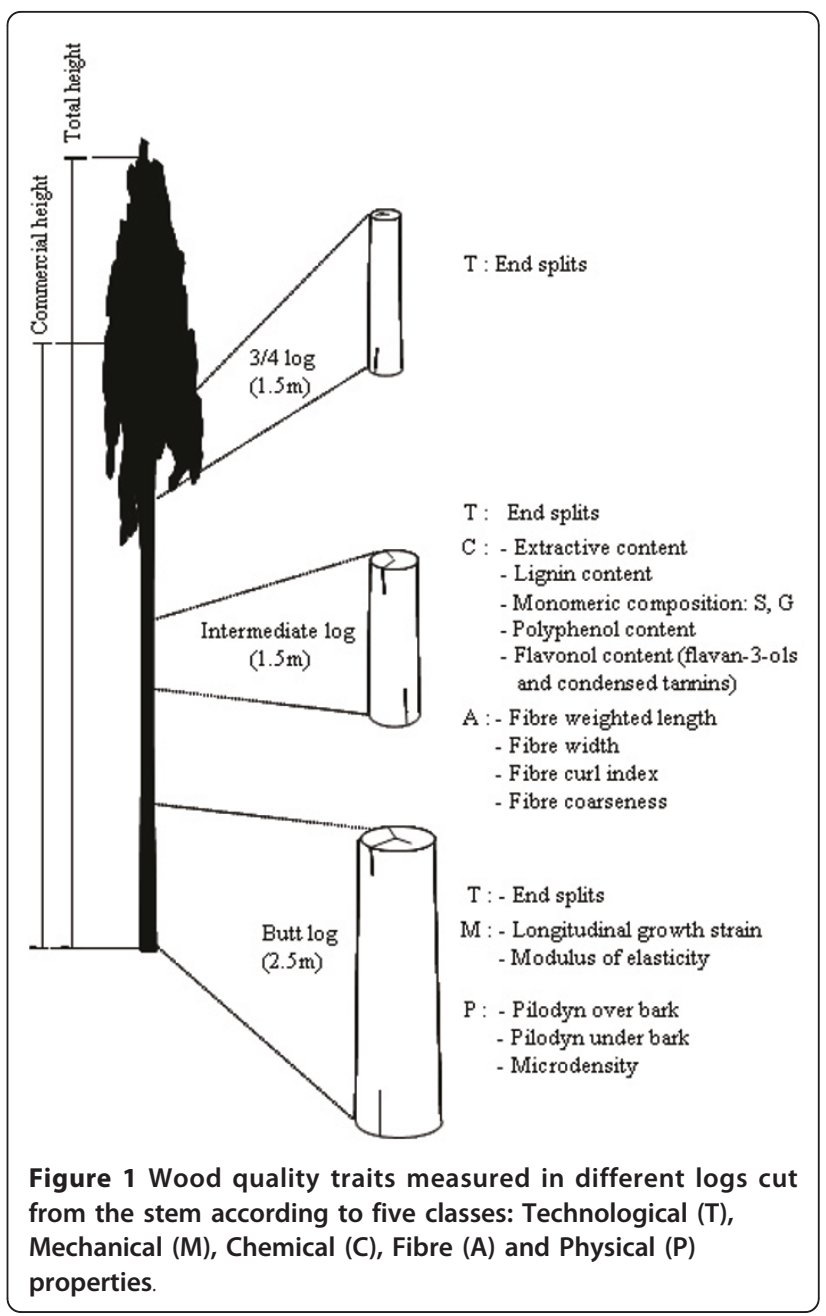

dry weight. Gallic acid aqueous solutions $\left(0-20 \mu \mathrm{g} \cdot \mathrm{mL}^{-1}\right)$ were used for calibration. For Fla quantification, $1 \mathrm{~mL}$ of supernatant was dried and suspended in $100 \mu \mathrm{L}$ methanol. Fla was quantified by a colorimetric method using 4-dimethylamino-cinnamaldehyde (DMACA Sigma) as chemical reagent [40]: $100 \mu \mathrm{L}$ of phenolic extract, $880 \mu \mathrm{L}$ of methanol and $20 \mu \mathrm{L}$ of DMACA solution $(100 \mathrm{mg}$ DMACA in $10 \mathrm{~mL}$ of $1.5 \mathrm{M}$ methanolic sulfuric acid) were mixed and incubated for $2 \mathrm{~h}$ at room temperature. Fla was determined spectrophotometrically at $630 \mathrm{~nm}$ using a standard curve based on catechin (0$15 \mu \mathrm{g} \cdot \mathrm{mL}^{-1}$ ) and expressed in $\mathrm{mg}$ equivalent of catechin per gram of dry weight.

\section{Assessment of growth stresses and related degrade}

i) One week after felling, the circumference in the middle of the $2.5 \mathrm{mg}$ butt log was divided into four to eight equal sectors depending on the diameter. At the middle of each sector, the "single hole" drilling method of Fournier et al. [41] was used to estimate the longitudinal growth strain (LGS) close to the trunk surface. This method measures the relative displacement of two pins 
inserted in the wood after releasing longitudinal growth stress in the outermost wood layer. A positive displacement resulting from shortening of the fibres, corresponds to the release of a tensile stress. Finally the mean of the four or eight measurements (according to trunk diameter) was used for QTL analysis.

ii) On each butt log, a splitting index (SI) was used to assess the intensity of the log end split. The index is calculated as follows:

$$
S I=\frac{\sum \text { Total cracks length at log end }}{\text { Diameter }}
$$

Three SI measurements were made one day (SId), one week (SIw) and one month (SIm) after the trees were felled. The average of basal and terminal log ends was used for QTL analysis for these three measurements.

\section{Longitudinal modulus of elasticity (MOE)}

Trees were cut into logs of $400 \mathrm{~mm}$ long at $1.30 \mathrm{~m}$ above the ground. From each log, one slab was taken out along the diameter in a north-south direction. Each slab was divided into specimens of constant dimension from the bark towards the pith. Three to eight specimens $400 \mathrm{~mm}$ long (longitudinal direction) $\times 20 \mathrm{~mm}$ thick (radial direction) $\times 40 \mathrm{~mm}$ wide (tangential direction) were prepared from each tree. A total of 808 specimens were available for the measurement of the longitudinal modulus of elasticity (MOE) which was measured on specimens at green condition using the non-destructive method of Brancheriau and Baillères [42] based on spectral analysis of natural bending vibrations in the tangential-longitudinal plane. This technique gave a relative accuracy estimated at $6 \%$ [42]. The measured values of $E$ were interpreted as the averaged values of MOE of concentric wood tissues included in each sample.

To facilitate the analysis of these data and provide a better understanding of the variability of wood, a method was developed to improve handling of withintree variation of wood properties using a few discrete data averaged on large sized specimens [8]. Based on a non-deterministic and non-parametric technique for describing continuous variation in wood characteristics, this is a new approach for statistical analyses and graphical presentation that does not use arbitrarily chosen mathematical models. Local and tree averaged E property increases with cambial age according to a sigmoid profile that can be described by three characteristic parameters:

- $\mathrm{E}_{\mathrm{p}}: \mathrm{MOE}$ at pith,

- $\mathrm{E}_{30}$ : average $\mathrm{MOE}$ at 30 months cambial age

- $\mathrm{E}_{2 \mathrm{i}}$ : average $\mathrm{MOE}$ at 2 times inflection point of cambial age vs. MOE

\section{Fibre properties}

Fibre properties were obtained from a disk sampled in the middle of the intermediate log. Fibre characteristics were determined using PQM 1000 apparatus. Measurements were made on 2-g samples of pulp. Three properties were estimated: fibre weighted length (FWL), which reduces the effect of small fibre fragments, coarseness (Coar) a measure of mass per unit length of fibre, and curl index (Curl) measured as [real length/projected length-1] $\times 100$ which is an assessment of the straightness of the fibre.

\section{Wood density}

Wood density was indirectly estimated at breast height before felling, using the Pilodyn ${ }^{\circledR}$ as described by Verhaegen et al. [21]. The penetration depth of the pilodyn pin (measured in millimetres, PIL) is an indirect estimation of wood density (WD), which is negatively correlated with WD. Five measurement dates were available, i.e. at month 14, 26, 38 (data already published, see [21]), and at month 52, and 59 (this study) after planting. At 59 months, one more pilodyn measurement was made under bark. Microdensity $(\mu \mathrm{D})$ profiles were also obtained on a disk cut at breast height, using the indirect X-ray method developed by Polge [43] and improved since then in different laboratories around the world [44]. The microdensity profile measures the radial variation of wood density at a fine scale $(25 \mu \mathrm{m})$, from pith to bark. In this study we used the average of the complete microdensity profile (i.e. mean microdensity) as an estimate of trunk density.

\section{Molecular markers \\ Choice of candidate genes}

These genes included: i) eight functional candidate genes involved in lignin biosynthesis, including genes of the common phenylpropanoid pathway [caffeic acid 3-0methyltransferase (COMTA and B), caffeoyl CoA 3-Omethyltransferase (CCoAOMT), 4-coumarate CoA ligase (4 CL), phenylalanine ammonia-lyase (PAL) and p-coumaroyl-CoA-3-hydroxylase $(\mathrm{C} 3 \mathrm{H})]$ and genes involved in the 'lignin specific' pathway [cinnamoyl-CoA-reductase (CCR) and cinnamyl alcohol dehydrogenase (CAD)], ii) two regulatory genes putatively involved in the regulation of these structural genes: EgMYB2, a member of the R2R3 MYB family of transcription factors [31] and a Rac-like small GTPase involved in cell differentiation during secondary xylem formation (EgROP1; [32]), and iii) 84 expressional candidate genes selected from a list of genes preferentially expressed in Eucalyptus wood forming tissue compared to leaf [29]. Other molecular markers

Molecular markers included: two symbiosis regulated genes (EgHypar, [45]; and EgTubA1, [46]), one paralogue 
of the leafy gene family (LFY1, $[47,48]$ ), one member of the Chalcone synthase gene family (CHS), three genes of the methionine pathway (SAH, SAMS, HMT from Kirst et al. [49]), 20 simple sequence repeats (SSRs) from Brondani et al. [50], and 147 Random Amplified Polymorphic DNA (RAPD) markers from Verhaegen et al. [21].

\section{Polymorphism detection and linkage mapping}

Gene polymorphism was revealed using the SSCP (single strand conformation polymorphism, [51]) technique as described in Gion et al. [34]. SSR genotyping was performed using LI-COR automated sequencers as described in Mariette et al. [52]. A map was constructed for each parent of the cross following the two-way pseudo-testcross mapping strategy [53], using Mapmaker/exp ver. 3.0 [54]. In brief, loci were assigned to linkage groups (LG) with a minimum LOD score of 3.0 and a maximum Kosambi distance of 40 centiMorgans (cM). The order of the markers was approximated using the FIRST ORDER function of Mapmaker. Framework maps were then constructed by comparing the likelihood of all permutations of all adjacent triplets using the RIPPLE function. Individual markers were dropped from each linkage group until a marker sequence was obtained that had an order at least 1,000 times better than alternative orders (i.e., log likelihood difference $\geq 3$ ). The markers that were dropped were placed on the framework map as accessory markers and located near the closest framework markers.

\section{QTL mapping}

For QTL detection, we used the Multiple Interval Mapping (MIM) procedure [55] implemented in MultiQTL V2.6 (Haifa, Israel, 2005; [http://www.multiqtl.com/]). MIM allows individual QTLs to be detected independently of background noise and of previously detected QTLs.

Multi-QTL uses statistical models to estimate the significance of a QTL, where models with one and two QTLs per LG are proposed. The single QTL model tests the null hypothesis that there is a single QTL on the $\mathrm{LG}$ against the absence of QTL $\left(\mathrm{H}_{1}\right.$ vs. $\left.\mathrm{H}_{0}\right)$. The two-linked QTL model tests the hypothesis of the presence of two QTLs on the LG: (1) against the hypothesis of the absence of QTL $\left(\mathrm{H}_{2}\right.$ vs. $\left.\mathrm{H}_{0}\right)$ and (2) against the hypothesis of the presence of a single QTL $\left(\mathrm{H}_{2}\right.$ vs. $\mathrm{H}_{1}$ ). The MIM procedure of Multi-QTL allows the appropriate model to be attributed to each LG. QTLs were detected in a two-step procedure: first a MIM was performed using a two-linked QTL model on each LG, then a MIM with either a two-linked QTL model on LGs harbouring two linked QTL from the first step, or a single QTL model on the other LGs, was performed.
Empirical statistical significance thresholds (p), determined by 1,000 permutations of the dataset, were used to declare the presence of a QTL [56]. In our study, QTLs were declared significant using a type I error rate of $10 \%$ at the genome level. Taking into account the mean number of markers per linkage group, this threshold roughly corresponds to a $1 \%$ error rate at the chromosome level [57]. Therefore, instead of the 5\% default chromosome level detection rate implemented in MultiQTL, we used a more stringent statistical threshold for MIM analyses. This contrasts with the recent use of multiQTL [57-59] where MIM analysis was performed with the default detection threshold (5\% at the chromosome level) and where a genome-wise p-value was computed a posteriori and separately based on the number of mapped loci. Such a procedure should be avoided because it does not take into account the proper type I error rate in the detection step.

The empirical confidence interval at 95\% for the QTL position and for the allelic effect was calculated using bootstrap analysis [60] with 5,000 resamplings. We defined the "position range" of a QTL as the range between the position calculated from the original dataset (P) and the position calculated from bootstrap analysis (PBS). The confidence interval of the QTL position was calculated relative to the PBS.

The allelic substitution effect of the QTL and the percentage of explained phenotypic variance (PEV) were calculated using the MIM procedure. For each significant QTL, the proportion of phenotypic variance explained was estimated as follows: $\mathrm{i} /$ for single-trait QTL analysis:

$\mathrm{PEV}=1 / 4 \mathrm{~d}^{2} / \sigma^{2} \mathrm{ph}$, where $\mathrm{d}$ is the substitution allelic effect and $\sigma^{2}$ is the phenotypic variance; ii/for twolinked QTL effect, PEV $=\left[\left(\mathrm{d}_{1}+\mathrm{d}_{2}\right)^{2} / 4-\mathrm{rd}_{1} \mathrm{~d}_{2}+4(1-\mathrm{r})\right.$ $\left.r \varepsilon^{2}\right] /\left(\sigma^{2}{ }_{p h}\right)$, where $d_{1}$ and $d_{2}$ are the effects of the two QTLs, $\varepsilon$ is the epistasis and $r$ is the rate of recombination between the mapped QTLs. Charts of linkage maps and QTL positions were drawn using MapChart version 2.2 [61].

\section{Probabilities of co-location of QTL/QTL and QTL/ Candidate Genes}

To test whether the overlap of QTLs for two traits was due to chance alone, we calculated the probability of cooccurrences of QTLs in the same genomic region under the null hypothesis of random distribution of QTLs, (adapted from Scotti-Saintagne et al. [57]). For this analysis, the genome was subdivided into $\mathrm{n}_{1}$ intervals. Each interval corresponded to the mean distance between the position of the highest LOD score from the composite interval mapping and the position of the mean value for maximum LOD score after bootstrap analysis. If $\mathrm{n}_{3}$ is the number of QTLs for the trait exhibiting the largest 
number of QTLs, $\mathrm{n}_{4}$ the number of QTLs for the second trait, and $n_{2}$ the number of QTLs shared by the two traits, then the probability of having $\mathrm{n}_{2}$ intervals in common is given by Lin et al. [62]:

$$
p=\frac{C_{n 3}^{n 2} \cdot C_{n 1-n 3}^{n 4-n 2}}{C_{n 1}^{n 4}}
$$

\section{Results \\ Variability and correlation between wood properties}

A total of 201 full-sibs of an interspecific hybrid progeny between E. urophylla and E. grandis were felled at 59 months and used to dissect wood properties. The statistics for each trait and their phenotypic correlations are listed in Tables 1 and 2. Coefficients of phenotypic variation (CPV) were rather low in the family tested (3 to 18\%), except for five traits (SId, SIw, SIm, Poly and Fla) for which CPV varied between 38\% and 59\%. As commonly reported for hardwoods and eucalypts in particular [63], S units (2504 mol.g ${ }^{-1}$ of lignin on average) were more abundant that $G$ units (624 mol.g ${ }^{-1}$ of lignin on average), S also presented a higher level of variability. No significant correlation was observed between traits belonging to different categories of WPs, except between density and modulus of elasticity (positive correlation). The correlation coefficient was high between S and G (0.6) and moderate between Klason lignin content (Klas) and the S/G ratio (-0.29), suggesting that trees with a higher lignin content had lower $S$ unit content. Poly and Fla contents were highly correlated (0.64). Fibre related traits had lower coefficients of variation than the other traits and were highly correlated with each other, either positively (WFL and Coar 0.73) or negatively (WFL and Curl -0.61, Coar and Curl -0.50). Slipping indexes were positively correlated (ranging from 0.38 to 0.74 ) and showed moderate correlation with LGS (0.34$0.41)$. A positive and strong age-age correlation was observed for Pil from age 14 to age 59 months and each Pil measurement over bark was strongly positively correlated with Pil under bark at 59 months. As expected, all Pil measurements were correlated $(-0.35$ to -0.55$)$ with mean microdensity. In addition, positive correlations were detected between growth (height and circumference measured at 59 months) on the one hand, and mechanical (LGS) and technological (SId, SIw) properties on the other hand. Growth traits were negatively correlated with density ( $\mu \mathrm{D}$ and Pil from age 14 to age 51 months) and Cir59 was also negatively correlated with the three measurements of modulus of elasticity.

\section{Genetic mapping}

A total of 76 codominant markers were added to the earlier version of the maps constructed by Verhaegen and Plomion [33] and Gion et al. [34]. Additional file 1 - Table S1 summarizes the mapping information for these new markers including 3 SCARs, 13 SSRs 15 STSs, 54 ESTs, of which 27 were mapped in both parents, and 38 and 20 were mapped in E. urophylla and the E. grandis parents, respectively. In all, 116 and 110 framework markers were localized on the E. urophylla and E. grandis maps covering 1,383 and 1,216 cM, respectively (additional file 2 - Table S2). For both parents, 11 LGs were identified, corresponding to the 11 chromosomes of the Eucalyptus genome.

The codominant markers made it possible to confirm the assignment of orthologous LGs between parental maps previously inferred from intercross (low informative) dominant markers [33]. In all, 27 bridges were used to align the male and female LGs. Nine orthologous regions were identified covering $434 \mathrm{cM}$ and 423 cM of the female (31\%) and the male (35\%) maps, respectively. This coverage percentage varied between LGs (see orange segments between orthologous markers in Figures 2 and 3).

\section{QTL analysis}

\section{Overview of the detected QTLS}

QTLs were detected for the 27 traits analysed by multiple interval mapping in E. urophylla and/or E. grandis (Table 3 and Figures 2 and 3). In E. urophylla, 94 QTLs were detected, including 34 "single QTL" and 30 "twolinked QTLs". In E. grandis, 33 QTLs were detected, including 27 "single QTL" and 3 "two-linked QTLs".

Among the 94 QTLs detected at the $10 \%$ genome wide level, most (87\%) were still significant at the $5 \%$ genome wide level. As shown in additional file 3 - Figure $\mathrm{S} 1,72 \%$ of the WP-QTLs were detected into five LGs (LG2, LG3, LG6, LG7 and LG11). For growth, 50\% of the QTLs were detected on LG1 and LG2.

While $62 \%$ of the QTLs had a rather limited effect (percent of phenotypic variance, PEV $<10 \%$ ), 38\% displayed an effect $\geq 10 \%$. The strong QTL effect (PEV > $10 \%$ ) represented $47 \%$ of the QTLs detected in E. urophylla but only $23 \%$ of those detected in the E. grandis. The PEV explained by each QTL varied from $4.1 \%$ to $42.2 \%$ for E. urophylla and from $5.3 \%$ to $18.6 \%$ for $E$. grandis. Maximum total PEV amounted to $58.7 \%$ in $E$. urophylla for $\mathrm{E}_{2 \mathrm{i}}$ and $38.8 \%$ in E. grandis for Pil26. However, given the size of the sample used in this study (between 140 to 199 trees phenotyped), it should be noted that the PEVs are probably biased upwards [64]. This is clearly illustrated in E. urophylla for Pil14 (142 trees phenotyped), Pil26 (140 trees) and $E_{2} \mathrm{i}$ (152 trees), for which the total PEV were the highest.

QTLs detected for each WP category

Mechanical and technological properties In E. urophylla, 34 QTLs (5 for LGS, 4 for SId, 1 for SIw, 2 for 
Table 1 Statistics for each wood quality related trait and growth: mean, standard deviation (SD) and coefficient of phenotypic variation (CPV)

\begin{tabular}{|c|c|c|c|c|c|}
\hline $\begin{array}{c}\text { Wood } \\
\text { Properties }\end{array}$ & Trait & Trait definition (unit) & Mean & SD & $\mathrm{CPV}$ \\
\hline \multirow{4}{*}{$\begin{array}{l}\text { Mechanical } \\
\text { properties } \\
\text { (M) }\end{array}$} & LGS & Mean Longitudinal Growth Strain $(\mu \mathrm{m})$ & 72 & 13 & 0.18 \\
\hline & $E_{p}$ & Primary value of Modulus of elasticity (GPa) & 9 & 1 & 0.14 \\
\hline & $E_{30}$ & Mean Modulus of elasticity at 30 months (GPa) & 11 & 1 & 0.12 \\
\hline & $E_{2 i}$ & Modulus of elasticity after inflection point (GPa) & 14 & 2 & 0.13 \\
\hline \multirow{3}{*}{$\begin{array}{c}\text { Technological } \\
\text { properties } \\
\text { (T) }\end{array}$} & Sld & Splitting Index at 1 day & 1.19 & 0.48 & 0.41 \\
\hline & SIw & Splitting Index at 1 week & 0.96 & 0.49 & 0.51 \\
\hline & $\mathrm{SIm}$ & Splitting Index at 1 months & 1.06 & 0.48 & 0.45 \\
\hline \multirow{7}{*}{$\begin{array}{l}\text { Physical } \\
\text { properties } \\
\text { (P) }\end{array}$} & Pil14 & Pilodyn at 14 months (mm) & 25 & 3 & 0.10 \\
\hline & Pil26 & Pilodyn at 26 months (mm) & 26 & 2 & 0.09 \\
\hline & Pil38 & Pilodyn 38 months (mm) & 25 & 3 & 0.11 \\
\hline & Pil51 & Pilodyn 51 months (mm) & 28 & 2 & 0.09 \\
\hline & Pil59 & Pilodyn 59 months (mm) & 27 & 3 & 0.11 \\
\hline & Pil59u & Pilodyn, under bark, 59 months (mm) & 22 & 3 & 0.13 \\
\hline & $\mu \mathrm{D}$ & Mean microdensity $\left(\mathrm{g} \cdot \mathrm{dm}^{-3}\right)$ & 501 & 40 & 0.08 \\
\hline \multirow{7}{*}{$\begin{array}{l}\text { Chemical } \\
\text { composition } \\
\text { (C) }\end{array}$} & Text & Extractive content (\%) & 3.70 & 0.62 & 0.17 \\
\hline & Klass & Lignin content (wood \%) & 24.6 & 0.8 & 0.03 \\
\hline & G & G content ( $\mu$ mol.g $\mathrm{g}^{-1}$ lignin) & 624 & 77 & 0.12 \\
\hline & S & $\mathrm{S}$ content ( $\mu \mathrm{mol}^{-\mathrm{g}^{-1}}$ lignin) & 2504 & 405 & 0.16 \\
\hline & $S / G$ & S/G ratio & 4.03 & 0.53 & 0.13 \\
\hline & Poly & Polyphenols content (mg. $\mathrm{g}^{-1}$ ) & 4551 & 1742 & 0.38 \\
\hline & Fla & Flavanols content $\left(\mathrm{mg} \cdot \mathrm{g}^{-1}\right)$ & 249 & 148 & 0.59 \\
\hline \multirow{4}{*}{$\begin{array}{l}\text { Anatomical properties } \\
\text { (A) }\end{array}$} & FWL & weighted fibre length ( $\mathrm{mm}$ ) & 1.28 & 0.05 & 0.04 \\
\hline & FW & Fibre width $(\mu \mathrm{m})$ & 33 & 1 & 0.03 \\
\hline & Coar & Fibre coarseness $\left(\mu \mathrm{g} \cdot \mathrm{mm}^{-1}\right)$ & 0.0966 & 0.0025 & 0.03 \\
\hline & Curl & Fibre curl index (\%) & 15.8 & 1.1 & 0.07 \\
\hline \multirow[t]{2}{*}{ Growth (G) } & $\mathrm{Ht} 59$ & Total height at 59 month old (m) & 24.2 & 2.4 & 0.10 \\
\hline & Cir59 & Circumference $(1.3 \mathrm{~m})$ at 59 month old $(\mathrm{cm})$ & 54 & 9 & 0.16 \\
\hline
\end{tabular}

SIm, 3 for $\mathrm{E}_{\mathrm{p}}$, 10 for $\mathrm{E}_{30}$ and 9 for $\mathrm{E}_{2 \mathrm{i}}$ ) were detected. The total PEV varied between $13.2 \%$ and $58.7 \%$. Three major QTL clusters were identified on LG7, LG10 and LG11. In E. grandis no QTL was detected.

Physical properties In E. urophylla, 35 wood density QTLs were detected with a total PEV varying from 26.3\% for Pil38 (3 QTLs) to 53.2\% for Pil26 (5 QTLs). In E. grandis 15 QTLs were detected with a total PEV varying from $13.7 \%$ for Pil38 (2 QTLs) to $38.8 \%$ for Pil26 (5 QTLs). Three major QTL clusters were identified at all the measurements dates on LG3 and LG11 for E. urophylla and on LG6 for E. grandis, reflecting the high phenotypic correlations between these traits. The linkage phase between QTLs and flanking markers was the same for the two clusters, only one change in the linkage phase was observed for Pil14 in LG3.

Chemical composition In E. urophylla, with the exception of S content, QTLs were detected for all the traits (17 QTLs in total). Total PEV varied from 7.7\% for Ext (1 QTL) to $52 \%$ for $\mathrm{S} / \mathrm{G}$ ratio (5 QTLs). In E. grandis far fewer QTLs were detected: 4 QTLs for lignin content (Klas), 2 for S/G ratio, 1 for Poly and 2 for Fla. Total PEV varied from $6.2 \%$ for Poly to $26.7 \%$ for Klas. Two clusters in LG6 and LG11 were identified on both parental maps. Interestingly, the 10 QTLs detected for lignin content were localized on 8 different chromosomes. S/G ratio QTLs shared orthologous genomic positions on LG6 and LG11 on both maps. 
Table 2 Matrix of significant Pearson correlation coefficients between studied traits $(p<1 \%)$

\begin{tabular}{|c|c|c|c|c|c|c|c|c|c|c|c|c|c|c|c|c|c|c|c|c|c|c|c|c|c|c|c|}
\hline & & \multicolumn{4}{|c|}{$M$} & \multicolumn{3}{|c|}{$\mathrm{T}$} & \multicolumn{4}{|c|}{ A } & \multicolumn{7}{|c|}{ C } & \multicolumn{7}{|c|}{ P } & \multirow{2}{*}{$\frac{\mathrm{G}}{\mathrm{Ht} 59}$} \\
\hline & & LGS & $E_{p}$ & $E_{30}$ & $E_{2 i}$ & SId & SIw & SIm & FWL & $\mathrm{FW}$ & Coar & Curl & Text & Klass & G & $S$ & $S / G$ & Poly & $\mathrm{Fla}$ & Pil14 & Pil26 & Pil38 & Pil51 & Pil59 & Pil59u & $\mu \mathrm{D}$ & \\
\hline \multirow[t]{3}{*}{$\bar{M}$} & $E_{p}$ & - & & & & & & & & & & & & & & & & & & & & & & & & & \\
\hline & $E_{30}$ & 0.24 & 0.88 & & & & & & & & & & & & & & & & & & & & & & & & \\
\hline & $E_{2 i}$ & - & 0.46 & 0.70 & & & & & & & & & & & & & & & & & & & & & & & \\
\hline \multirow[t]{3}{*}{$T$} & Sld & 0.34 & - & 0.23 & - & & & & & & & & & & & & & & & & & & & & & & \\
\hline & SIw & 0.41 & - & 0.29 & - & 0.74 & & & & & & & & & & & & & & & & & & & & & \\
\hline & SIm & 0.36 & 0.20 & 0.25 & 0.24 & 0.38 & 0.60 & & & & & & & & & & & & & & & & & & & & \\
\hline \multirow[t]{4}{*}{ A } & FWL & 0.22 & - & - & - & - & 0.20 & - & & & & & & & & & & & & & & & & & & & \\
\hline & $\mathrm{FW}$ & - & - & -0.28 & - & - & - & - & -0.46 & & & & & & & & & & & & & & & & & & \\
\hline & Coar & - & - & - & - & - & - & - & 0.73 & -0.31 & & & & & & & & & & & & & & & & & \\
\hline & Curl & & - & 0.21 & - & - & - & - & -0.61 & 0.95 & -0.50 & & & & & & & & & & & & & & & & \\
\hline \multirow[t]{7}{*}{ C } & Text & -0.23 & - & - & - & - & - & - & -0.21 & 0.24 & - & 0.23 & & & & & & & & & & & & & & & \\
\hline & Klass & - & - & -0.21 & - & - & - & - & - & 0.34 & - & 0.35 & - & & & & & & & & & & & & & & \\
\hline & G & - & - & - & - & - & - & - & - & - & - & - & - & - & & & & & & & & & & & & & \\
\hline & S & - & - & - & - & - & -0.19 & - & - & - & - & - & - & -0.37 & 0.60 & & & & & & & & & & & & \\
\hline & $S / G$ & - & - & -0.20 & - & - & -0.22 & - & - & - & - & - & 0.19 & -0.29 & -0.24 & 0.64 & & & & & & & & & & & \\
\hline & Poly & & - & & - & - & - & - & 0.20 & 0.22 & - & 0.24 & 0.78 & 0.28 & - & & & & & & & & & & & & \\
\hline & Fla & - & - & - & - & - & - & - & - & - & - & - & 0.50 & 0.25 & & - & & 0.64 & & & & & & & & & \\
\hline \multirow[t]{7}{*}{ P } & Pil14 & - & -0.55 & -0.61 & -0.49 & - & - & - & - & - & - & - & - & - & - & - & - & - & - & & & & & & & & \\
\hline & Pil26 & - & -0.47 & -0.59 & -0.51 & - & - & - & - & - & - & - & - & - & - & - & - & - & - & 0.61 & & & & & & & \\
\hline & Pil38 & - & -0.32 & -0.39 & -0.44 & - & - & - & - & - & - & - & - & - & - & - & - & - & - & 0.50 & 0.65 & & & & & & \\
\hline & Pil51 & - & -0.40 & -0.51 & -0.52 & - & - & - & - & - & - & - & - & - & - & - & - & - & - & 0.48 & 0.66 & 0.65 & & & & & \\
\hline & Pil59 & - & -0.20 & -0.28 & -0.22 & - & - & - & - & - & - & - & - & - & - & - & & - & - & 0.32 & 0.48 & 0.51 & 0.59 & & & & \\
\hline & Pil59u & - & -0.31 & -0.34 & -0.26 & - & - & - & - & - & - & - & - & - & & & - & - & - & 0.30 & 0.40 & 0.36 & 0.50 & 0.52 & & & \\
\hline & $\mu \mathrm{D}$ & 0.23 & 0.43 & 0.58 & 0.51 & - & - & 0.30 & - & - & - & - & - & - & - & - & -0.22 & - & - & -0.43 & -0.55 & -0.42 & -0.50 & -0.35 & -0.36 & & \\
\hline \multirow[t]{2}{*}{ G } & $\mathrm{Ht} 59$ & 0.23 & - & - & - & 0.43 & 0.36 & - & - & - & - & - & - & - & - & - & - & - & - & 0.36 & 0.42 & 0.34 & 0.26 & - & - & - & \\
\hline & Cir59 & - & -0.26 & -0.28 & -0.30 & 0.38 & 0.29 & - & - & - & - & - & - & - & - & - & - & - & - & 0.61 & 0.58 & 0.53 & 0.48 & 0.35 & 0.25 & -0.26 & 0.83 \\
\hline
\end{tabular}

Non-significant correlations are indicated by " ${ }^{-}$. Abbreviations are the same as in table 1. 

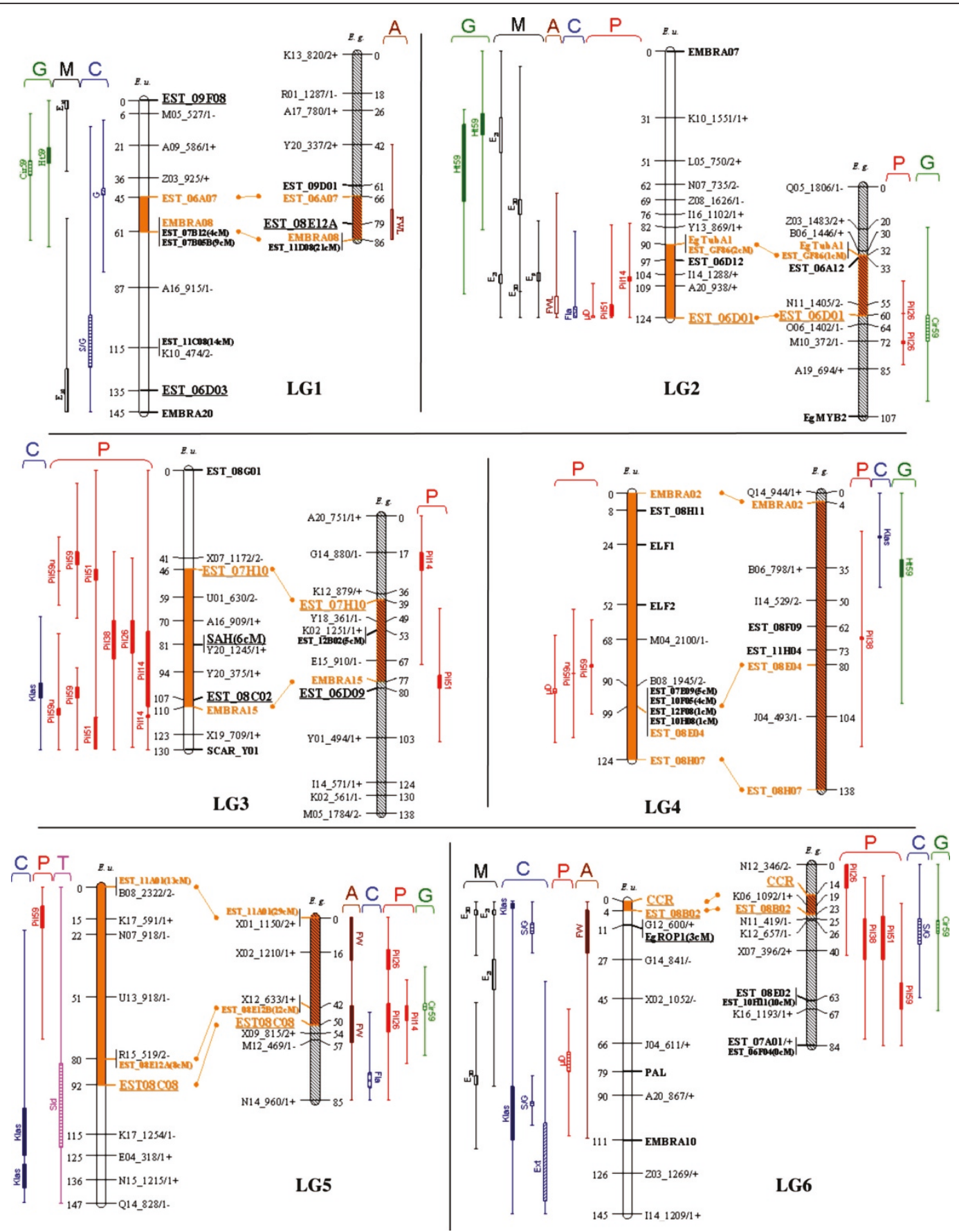

Figure 2 Detection of QTLs for wood properties and growth related traits on the genetic maps of $E$. urophylla and $E$. grandis for the linkage groups 1 to 6 .

Anatomical properties In E. urophylla, 1 QTL was detected for FWL (12.8\%, LG2). In E. grandis, 1 QTL for FWL (8.4\%, LG1) and 1 QTL for Curl (11.1\%, LG7) were detected. No QTL was significant for Coar.

Growth In E. urophylla, 4 QTLs were detected for growth on LG1, LG7 and LG11 explaining from 4.1\% to $11.9 \%$ of phenotypic variation. Two-linked QTLs were also detected on LG2 accounting for $42.2 \%$ of phenotypic variance. In E. grandis, only 4 QTLs were detected for growth $(7.9 \%$ for $\mathrm{Ht} 59$ on LG4 and 5.1 to $6.8 \%$ for Cir59 on LG2, LG5 and LG6).

\section{Co-locations between QTLs}

Two types of QTL co-locations were observed. First, "expected" co-locations consistent with significant 


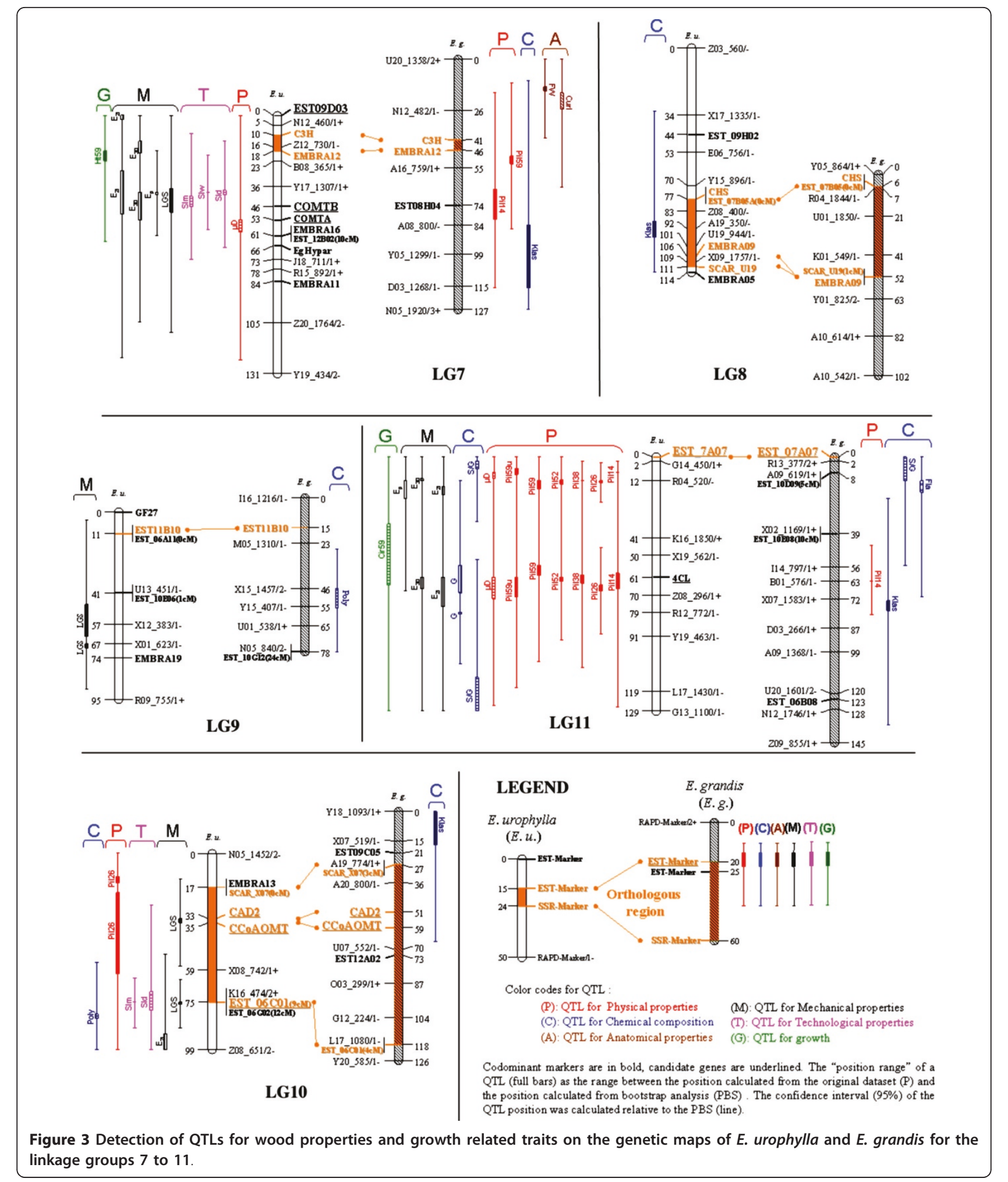

phenotypic correlations found between traits. A total of 97 such "expected" co-locations between WP QTLs were observed in E. urophylla and 3 in E. grandis, 44\% being wood density QTLs. Indeed, wood density was measured at different ages and these traits presented relatively high phenotypic correlations (Pearson coefficient ranging from 0.32 to 0.66 ). Co-located QTLs were mainly distributed in LG 3 and LG11 in E. urophylla 
Table 3 QTLs detected by multiple interval mapping in E. urophylla (E.u.) and E. grandis (E.g.) for i) mechanical properties; longitudinal growth strain (LGS) and modulus of elasticity (Ep E30, and E2i), ii) technological properties; splitting index (SId, SIs and SIm), iii) Physical properties (Pil, $\mu \mathrm{D})$, iv) chemical properties; lignin content (Klas), monomeric composition (S, G, S/G), extractive contents (Ext), phenolic content (Poly) and flavanol content (Fla), and v) fibre properties; fibre weighted length (FWL) and fibre curl index (Curl), vi) growth, total height and circumference (1.3 m) at 59 months (Ht59, Cir59)

\begin{tabular}{|c|c|c|c|c|c|c|c|c|c|c|c|c|c|c|c|c|}
\hline Species & $\begin{array}{c}\text { Trait } \\
\text { category }\end{array}$ & Trait & LG & $n$ & $\begin{array}{l}\text { LOD } \\
\text { score }\end{array}$ & $\begin{array}{l}\mathrm{H}_{1} v s \mathrm{H}_{0} \\
\mathrm{H}_{2} v s \mathrm{H}_{0}\end{array}$ & $\mathrm{H}_{2} v s \mathrm{H}_{1}$ & $\begin{array}{c}\text { QTL } \\
\text { Model }\end{array}$ & $\begin{array}{c}\mathrm{P} 1 \\
\text { (cM) }\end{array}$ & $\begin{array}{c}\mathrm{P} 2 \\
(\mathrm{cM})\end{array}$ & d1 & $\Delta 1$ & d2 & $\Delta 2$ & $\begin{array}{l}\text { PEV } \\
(\%)\end{array}$ & $\begin{array}{l}\text { PEVtot } \\
(\%)\end{array}$ \\
\hline \multirow[t]{44}{*}{ E.u. } & $\begin{array}{l}\text { Mechanical properties } \\
\text { (M) }\end{array}$ & LGS & 7 & 198 & 3.5 & 0.0010 & - & 1 & 36 & - & 5.7 & 0.44 & - & - & 5.2 & 36.3 \\
\hline & & LGS & 9 & 198 & 4.7 & 0.0020 & 0.0080 & 2 & 63 & 69 & 24.5 & 1.88 & -20.7 & -1.59 & 19.5 & \\
\hline & & LGS & 10 & 198 & 6.9 & $<10^{-4}$ & $<10^{-4}$ & 2 & 33 & 75 & 4.8 & 0.37 & -8.8 & -0.68 & 11.7 & \\
\hline & & $E_{p}$ & 2 & 191 & 3.8 & $<10^{-4}$ & - & 1 & 107 & - & -0.73 & -0.73 & - & - & 7.7 & 22.5 \\
\hline & & $E_{p}$ & 7 & 191 & 4.2 & 0.0010 & - & 1 & 40 & & 0.78 & 0.78 & - & - & 8.9 & \\
\hline & & $E_{p}$ & 11 & 191 & 3.0 & 0.0010 & - & 1 & 12 & - & 0.63 & 0.63 & - & - & 5.8 & \\
\hline & & $E_{30}$ & 1 & 191 & 5.3 & $<10^{-4}$ & $<10^{-4}$ & 2 & 0 & 145 & 0.51 & 0.51 & -0.50 & -0.50 & 8.4 & 52.0 \\
\hline & & $E_{30}$ & 2 & 191 & 7.2 & $<10^{-4}$ & 0.0010 & 2 & 76 & 112 & 0.25 & 0.25 & -0.97 & -0.97 & 12.5 & \\
\hline & & $E_{30}$ & 6 & 191 & 7.5 & $<10^{-4}$ & $<10^{-4}$ & 2 & 4 & 85 & 0.66 & 0.66 & -0.63 & -0.63 & 11.6 & \\
\hline & & $E_{30}$ & 7 & 191 & 9.3 & $<10^{-4}$ & $<10^{-4}$ & 2 & 13 & 39 & 0.53 & 0.53 & 0.47 & 0.47 & 11.6 & \\
\hline & & $E_{30}$ & 11 & 191 & 6.5 & $<10^{-4}$ & $<10^{-4}$ & 2 & 12 & 61 & 0.64 & 0.64 & 0.21 & 0.21 & 8.0 & \\
\hline & & $E_{2 i}$ & 2 & 152 & 6.7 & $<10^{-4}$ & $<10^{-4}$ & 2 & 31 & 104 & 0.84 & 0.42 & -1.27 & -0.64 & 15.4 & 58.7 \\
\hline & & $E_{2 i}$ & 6 & 152 & 5.1 & $<10^{-4}$ & $<10^{-4}$ & 2 & 4 & 27 & 1.26 & 0.63 & -0.89 & -0.45 & 8.1 & \\
\hline & & $E_{2 i}$ & 7 & 152 & 9.6 & $<10^{-4}$ & $<10^{-4}$ & 2 & 0 & 28 & 0.93 & 0.47 & 0.69 & 0.35 & 14.5 & \\
\hline & & $E_{2 i}$ & 10 & 152 & 3.4 & 0.0010 & - & 1 & 99 & - & 0.78 & 0.39 & - & - & 4.5 & \\
\hline & & $E_{2 i}$ & 11 & 152 & 8.5 & $<10^{-4}$ & $<10^{-4}$ & 2 & 19 & 61 & 1.30 & 0.65 & 0.42 & 0.21 & 16.1 & \\
\hline & Technological properties & Sld & 5 & 199 & 3.9 & 0.0030 & 0.0050 & 2 & 121 & 125 & 0.85 & 1.77 & -0.92 & -1.92 & 13.5 & \\
\hline & & SId & 7 & 199 & 4.4 & $<10^{-4}$ & - & 1 & 38 & - & 0.28 & 0.58 & - & - & 8.6 & \\
\hline & & Sld & 10 & 199 & 2.0 & 0.0090 & - & 1 & 79 & - & -0.20 & -0.42 & - & - & 4.1 & 26.0 \\
\hline & & SIw & 7 & 192 & 5.2 & $<10^{-4}$ & - & 1 & 39 & - & 0.35 & 0.71 & - & - & 13.2 & 13.2 \\
\hline & & SIm & 7 & 190 & 4.0 & $<10^{-4}$ & & 1 & 46 & - & 0.28 & 0.58 & - & - & 8.6 & \\
\hline & & SIm & 10 & 190 & 4.0 & $<10^{-4}$ & - & 1 & 75 & - & -0.28 & -0.58 & - & - & 8.5 & 17.1 \\
\hline & Physical properties & Pil14 & 2 & 142 & 4.0 & 0.0010 & - & 1 & 105 & - & 1.36 & 0.45 & - & - & 6.7 & \\
\hline & & Pil14 & 3 & 142 & 7.0 & $<10^{-4}$ & $<10^{-4}$ & 2 & 110 & 114 & -4.37 & -1.46 & 5.63 & 1.88 & 18.9 & \\
\hline & & Pil14 & 11 & 142 & 11.0 & $<10^{-4}$ & $<10^{-4}$ & 2 & 8 & 59 & -2.37 & -0.79 & -0.73 & -0.24 & 25.4 & 51.1 \\
\hline & & Pil26 & 3 & 140 & 3.4 & $<10^{-4}$ & - & 1 & 70 & - & 1.09 & 0.55 & - & - & 5.3 & \\
\hline & & Pil26 & 10 & 140 & 5.0 & 0.0010 & 0.0010 & 2 & 12 & 20 & -4.33 & -2.17 & 3.09 & 1.55 & 24.5 & \\
\hline & & Pil26 & 11 & 140 & 12.5 & $<10^{-4}$ & $<10^{-4}$ & 2 & 12 & 64 & -1.58 & -0.79 & -1.35 & -0.68 & 23.4 & 53.2 \\
\hline & & Pil38 & 3 & 199 & 2.8 & 0.0030 & - & 1 & 70 & - & 1.27 & 0.42 & - & - & 5.7 & \\
\hline & & Pil38 & 11 & 199 & 10.0 & $<10^{-4}$ & 0.0020 & 2 & 12 & 60 & -1.91 & -0.64 & -1.08 & -0.36 & 20.7 & 26.3 \\
\hline & & Pil51 & 2 & 199 & 4.2 & $<10^{-4}$ & - & 1 & 123 & - & 1.58 & 0.79 & - & - & 10.4 & \\
\hline & & Pil51 & 3 & 199 & 5.6 & $<10^{-4}$ & 0.0010 & 2 & 46 & 130 & 0.67 & 0.34 & 1.32 & 0.66 & 9.6 & \\
\hline & & Pil51 & 11 & 199 & 9.7 & $<10^{-4}$ & $<10^{-4}$ & 2 & 12 & 61 & -1.40 & -0.70 & -1.11 & -0.56 & 16.4 & 36.4 \\
\hline & & Pil59 & 3 & 198 & 8.6 & $<10^{-4}$ & $<10^{-4}$ & 2 & 44 & 101 & 1.05 & 0.35 & 1.13 & 0.38 & 12.8 & \\
\hline & & Pil59 & 4 & 196 & 3.6 & $<10^{-4}$ & - & 1 & 80 & - & -1.31 & -0.44 & - & - & 7.7 & \\
\hline & & Pil59 & 5 & 198 & 2.7 & 0.0060 & - & 1 & 9 & - & 0.98 & 0.33 & - & - & 4.4 & \\
\hline & & Pil59 & 11 & 198 & 9.0 & $<10^{-4}$ & $<10^{-4}$ & 2 & 12 & 55 & -1.34 & -0.45 & -0.84 & -0.28 & 14.5 & 42.5 \\
\hline & & Pil59u & 3 & 198 & 9.5 & $<10^{-4}$ & $<10^{-4}$ & 2 & 47 & 114 & 1.46 & 0.49 & 1.00 & 0.33 & 15.4 & \\
\hline & & Pil59u & 4 & 198 & 2.5 & 0.0050 & - & 1 & 84 & - & -1.10 & -0.37 & - & - & 5.3 & \\
\hline & & Pil59u & 11 & 198 & 6.9 & $<10^{-4}$ & $<10^{-4}$ & 2 & 6 & 61 & -1.53 & -0.51 & -0.66 & -0.22 & 13.8 & 34.5 \\
\hline & & $\mu \mathrm{D}$ & 2 & 199 & 4.9 & $<10^{-4}$ & - & 1 & 124 & - & -25 & -0.63 & - & - & 9.9 & 39.5 \\
\hline & & $\mu \mathrm{D}$ & 4 & 197 & 3.4 & $<10^{-4}$ & - & 1 & 93 & - & 18 & 0.45 & - & - & 5.4 & \\
\hline & & $\mu \mathrm{D}$ & 6 & 199 & 4.1 & $<10^{-4}$ & - & 1 & 75 & - & -21 & -0.53 & - & - & 7.3 & \\
\hline & & $\mu \mathrm{D}$ & 7 & 199 & 4.3 & $<10^{-4}$ & - & 1 & 53 & - & 20 & 0.50 & - & - & 6.3 & \\
\hline
\end{tabular}


Table 3 QTLs detected by multiple interval mapping in E. urophylla (E.u.) and E. grandis (E.g.) for i) mechanical properties; longitudinal growth strain (LGS) and modulus of elasticity (Ep E30, and E2i), ii) technological properties; splitting index (SId, SIs and SIm), iii) Physical properties (Pil, $\mu \mathrm{D})$, iv) chemical properties; lignin content (Klas), monomeric composition (S, G, S/G), extractive contents (Ext), phenolic content (Poly) and flavanol content (Fla), and v) fibre properties; fibre weighted length (FWL) and fibre curl index (Curl), vi) growth, total height and circumference (1.3 $\mathrm{m}$ ) at 59 months (Ht59, Cir59) (Continued)

\begin{tabular}{|c|c|c|c|c|c|c|c|c|c|c|c|c|c|c|c|}
\hline \multirow{13}{*}{$\begin{array}{l}\text { Chemical } \\
\text { composition } \\
\text { (C) }\end{array}$} & $\mu \mathrm{D}$ & 11 & 199 & 6.3 & $<10^{-4}$ & 0.0010 & 2 & 8 & 61 & 21 & 0.53 & 10 & 0.25 & 10.5 & \\
\hline & Klas & 3 & 189 & 4.2 & 0.0010 & - & 1 & 106 & - & -0.43 & -0.54 & - & - & 6.8 & \\
\hline & Klas & 5 & 189 & 5.4 & 0.0010 & 0.0010 & 2 & 125 & 140 & -0.78 & -0.98 & 0.64 & 0.80 & 11.5 & \\
\hline & Klas & 6 & 189 & 8.6 & $<10^{-4}$ & 0.0060 & 2 & 1 & 111 & -0.62 & -0.78 & 0.15 & 0.19 & 14.7 & \\
\hline & Klas & 8 & 189 & 3.1 & 0.0020 & - & 1 & 96 & - & 0.41 & 0.51 & - & - & 6 & 39 \\
\hline & $\mathrm{S} / \mathrm{G}$ & 1 & 189 & 3.2 & 0.0010 & - & 1 & 124 & - & -0.24 & -0.45 & - & - & 5 & \\
\hline & $\mathrm{S} / \mathrm{G}$ & 6 & 189 & 20.3 & $<10^{-4}$ & $<10^{-4}$ & 2 & 15 & 95 & 0.49 & 0.92 & 0.39 & 0.74 & 37 & \\
\hline & $\mathrm{S} / \mathrm{G}$ & 11 & 189 & 6.6 & $<10^{-4}$ & $<10^{-4}$ & 2 & 2 & 129 & -0.26 & -0.49 & -0.21 & -0.40 & 10 & 52 \\
\hline & Ext & 6 & 188 & 2.7 & 0.0070 & - & 1 & 139 & - & 0.34 & 0.55 & & - & 7.7 & 7.7 \\
\hline & G & 1 & 189 & 3.7 & $<10^{-4}$ & - & 1 & 41 & - & 44.3 & 0.58 & - & - & 8.3 & \\
\hline & G & 11 & 189 & 5.4 & $<10^{-4}$ & 0.0020 & 2 & 69 & 79 & 90.2 & 1.17 & -84.5 & -1.10 & 13.0 & 21.2 \\
\hline & Poly & 10 & 183 & 2.5 & 0.0040 & - & 1 & 83 & - & -1026 & -0.59 & - & - & 8.7 & 8.7 \\
\hline & Fla & 2 & 183 & 2.6 & 0.0010 & - & 1 & 124 & - & -87 & -0.59 & - & - & 8.7 & 8.7 \\
\hline \multirow[t]{2}{*}{ Anatomical properties (A) } & FWL & 2 & 177 & 3.5 & 0.0010 & - & 1 & 122 & - & -0.04 & -0.80 & - & - & 12.8 & 12.8 \\
\hline & FW & 6 & 177 & 2.8 & 0.0070 & - & 1 & 4 & - & -0.52 & -0.52 & - & - & 7.1 & 7.1 \\
\hline \multirow[t]{5}{*}{$\begin{array}{l}\text { Growth } \\
(\mathrm{G})\end{array}$} & $\mathrm{Ht} 59$ & 1 & 199 & 3.3 & $<10^{-4}$ & - & 1 & 22 & - & 0.80 & 0.33 & - & - & 4.1 & \\
\hline & $\mathrm{Ht} 59$ & 2 & 199 & 21.2 & 0.0090 & $<10^{-4}$ & 2 & 29 & 34 & -5.78 & -2.41 & 5.62 & 2.34 & 42.2 & \\
\hline & $\mathrm{Ht} 59$ & 7 & 199 & 4.0 & $<10^{-4}$ & - & 1 & 18 & - & 0.90 & 0.38 & - & - & 4.7 & 51.0 \\
\hline & Cir59 & 1 & 198 & 5.1 & $<10^{-4}$ & - & 1 & 28 & - & 5.8 & 0.64 & - & - & 11.9 & 19.5 \\
\hline & Cir59 & 11 & 198 & 2.7 & 0.0045 & - & 1 & 34 & - & -4.7 & -0.52 & - & - & 7.6 & \\
\hline Physical & Pil14 & 3 & 142 & 2.5 & 0.0100 & - & 1 & 17 & - & -1.20 & -0.40 & & - & 5.3 & \\
\hline & Pil14 & 5 & 142 & 3.1 & $<10^{-4}$ & - & 1 & 42 & - & 1.45 & 0.48 & - & - & 7.6 & \\
\hline & Pil14 & 7 & 142 & 2.5 & 0.0100 & - & 1 & 81 & - & -1.45 & -0.48 & - & - & 7.6 & \\
\hline & Pil14 & 11 & 142 & 4.4 & $<10^{-4}$ & - & 1 & 63 & - & 1.70 & 0.57 & - & - & 10.5 & 31.1 \\
\hline & Pil26 & 2 & 140 & 5.8 & $<10^{-4}$ & $<10^{-4}$ & 2 & 59 & 72 & 2.92 & 1.46 & -2.65 & -1.33 & 18.6 & \\
\hline & Pil26 & 5 & 140 & 6.3 & $<10^{-4}$ & $<10^{-4}$ & 2 & 14 & 41 & -0.64 & -0.32 & 1.93 & 0.97 & 12.8 & \\
\hline & Pil26 & 6 & 140 & 3.7 & $<10^{-4}$ & - & 1 & 0 & - & 1.27 & 0.64 & - & - & 7.4 & 38.8 \\
\hline & Pil38 & 4 & 199 & 3.1 & 0.0040 & - & 1 & 67 & - & 1.45 & 0.48 & - & - & 8.0 & \\
\hline & Pil38 & 6 & 199 & 2.8 & 0.0030 & - & 1 & 25 & - & 1.27 & 0.42 & - & - & 5.7 & 13.7 \\
\hline & Pil51 & 3 & 199 & 3.2 & 0.0010 & - & 1 & 80 & - & 1.36 & 0.68 & - & - & 7.6 & \\
\hline & Pil51 & 6 & 199 & 3.5 & $<10^{-4}$ & - & 1 & 24 & - & 1.31 & 0.66 & - & - & 7.0 & 14.7 \\
\hline & Pil59 & 6 & 199 & 2.8 & 0.0020 & - & 1 & 67 & - & 1.14 & 0.38 & - & - & 5.9 & \\
\hline & Pil59 & 7 & 199 & 2.5 & 0.0040 & - & 1 & 53 & - & -1.17 & -0.39 & - & - & 6.3 & 12.2 \\
\hline Chemical & Klas & 4 & 189 & 3.2 & 0.0010 & - & 1 & 20 & - & -0.52 & -0.65 & - & - & 9.5 & \\
\hline & Klas & 7 & 189 & 3.3 & 0.0020 & - & 1 & 116 & - & -0.43 & -0.54 & - & - & 6.3 & \\
\hline & Klas & 10 & 189 & 2.9 & 0.0030 & - & 1 & 0 & - & -0.39 & -0.49 & - & - & 5.3 & \\
\hline & Klas & 11 & 189 & 3.1 & 0.0020 & - & 1 & 73 & - & -0.40 & -0.50 & - & - & 5.7 & 26.7 \\
\hline & $S / G$ & 6 & 189 & 2.9 & $<10^{-4}$ & - & 1 & 37 & - & 0.28 & 0.53 & - & - & 7.2 & \\
\hline & $S / G$ & 11 & 189 & 2.9 & 0.0050 & - & 1 & 0 & - & 0.28 & 0.53 & & - & 6.8 & 14.0 \\
\hline & Poly & 9 & 183 & 2.5 & 0.0010 & - & 1 & 46 & - & 863 & 0.50 & - & - & 6.2 & 6.2 \\
\hline & $\mathrm{Fla}$ & 5 & 183 & 3.3 & $<10^{-4}$ & - & 1 & 79 & - & 90 & 0.61 & - & - & 9.6 & \\
\hline & Fla & 11 & 183 & 4.4 & $<10^{-4}$ & - & 1 & 12 & - & 100 & 0.68 & - & - & 11.8 & 21.4 \\
\hline
\end{tabular}


Table 3 QTLs detected by multiple interval mapping in E. urophylla (E.u.) and E. grandis (E.g.) for i) mechanical properties; longitudinal growth strain (LGS) and modulus of elasticity (Ep E30, and E2i), ii) technological properties; splitting index (SId, SIs and SIm), iii) Physical properties (Pil, $\mu \mathrm{D})$, iv) chemical properties; lignin content (Klas), monomeric composition (S, G, S/G), extractive contents (Ext), phenolic content (Poly) and flavanol content (Fla), and v) fibre properties; fibre weighted length (FWL) and fibre curl index (Curl), vi) growth, total height and circumference (1.3 $\mathrm{m}$ ) at 59 months (Ht59, Cir59) (Continued)

$\begin{array}{ccccccc}\begin{array}{c}\text { Anatomical properties } \\ \text { (A) }\end{array} & \text { FWL } & 1 & 166 & 3.1 & 0.0010 & - \\ & & & & & & \\ & \text { FW } & 5 & 177 & 4.4 & <10^{-4} & <10^{-4} \\ & \text { FW } & 7 & 178 & 4.0 & <10^{-4} & - \\ \text { Growth } & \text { Curl } & 7 & 177 & 2.9 & 0.0020 & - \\ (G) & \text { Ht59 } & 4 & 186 & 2.99 & 0.0010 & - \\ & \text { Cir59 } & 2 & 198 & 2.60 & 0.0040 & - \\ & \text { Cir59 } & 5 & 198 & 2.80 & 0.0015 & - \\ & \text { Cir59 } & 6 & 198 & 3.42 & <10^{-4} & -\end{array}$

\begin{tabular}{cccccccccc}
1 & 86 & - & -0.03 & -0.60 & - & - & 8.4 & 8.4 \\
2 & 0 & 42 & -0.47 & -0.47 & -0.59 & -0.59 & 11.1 & \\
1 & 14 & - & -0.74 & -0.74 & - & - & 13.9 & 25 \\
1 & 17 & - & -0.66 & -0.60 & - & - & 11.1 & 11.1 \\
1 & 31 & - & 1.34 & 0.56 & - & - & 7.9 & 7.9 \\
1 & 72 & - & -3.7 & -0.41 & - & - & 5.1 & \\
1 & 45 & - & 4.0 & 0.44 & - & - & 6.0 & \\
1 & 26 & - & 4.2 & 0.47 & - & - & 6.8 & 17.9 \\
\hline
\end{tabular}

QTLs location is given in cM from the top marker of the linkage group. Values of the maximum LOD-score and probability associated to the 1-QTL (H1 vs H0) or 2-QTL ( $\mathrm{H} 2$ vs $\mathrm{H} 0$ and $\mathrm{H} 2$ vs $\mathrm{H} 1$ ) models are given for each QTL after 1,000 permutations. Difference between the two QTL allele effects (d1 and d2) also expressed in phenotypic standard deviations ( $\Delta 1$ and $\Delta 2$ ). The percentage of phenotypic variation explained for each QTL (PEV) and the total PEV are also provided.

and LG6 in E. grandis. Mechanical and technological properties (LGS, SI and E traits) also showed high correlations (0.34 - 0.74) and co-located QTLs in E. urophylla (LG7 and LG10). The same result was observed on LG11 with QTL co-locations for Pil and E, which were negatively correlated. However, it should be noted that significant correlation did not always result in co-located QTLs. This was the case for Ht59 and Pil in both parents, despite significant correlations (0.26-0.42) and between Ht59 and mechanical properties $(0.23)$ or technological properties (0.36-0.43).

More surprisingly, "unexpected" co-locations were observed between uncorrelated traits (23 in E. urophylla and 5 in E. grandis), in E. urophylla on LG2 between wood density (Pil51 and $\mu \mathrm{D})$, chemical composition (Fla) and anatomical characteristics (FWL), on LG5 between technological (SId) and chemical (Klass) properties, on LG6 between chemical (S/G) and wood density (Pil38 and Pil51), and on LG11 between the cluster of WD QTLs and chemical properties (S/G and G content); in E. grandis on LG5 between density (Pil14, Pil26) and FW, on LG6 between WD (Pil38 and Pil51) and $\mathrm{S} / \mathrm{G}$ ratio.

Overall, multiple co-locations were much more frequent for pairs of correlated traits (31 pairs showing at least 2 co-locations vs. 27 pairs with one co-location) compared to non-correlated traits (1 pair with at least 2 co-locations vs. 26 pairs with one co-location).

Finally, the probability that these co-locations were observed by chance is shown in Additional file 4 - Table S3 for the different pairs of traits. On average, the mean interval length as defined in the Material and Methods section was $8.5 \mathrm{cM}$ for $E$. urophylla and $9.6 \mathrm{cM}$ for $E$. grandis. The length of the female map was 1,383 cM, and the number of intervals that could be compared was 163 . The number of intervals on the male map was $127(1,216 \mathrm{cM})$. For $79 \%$ of the co-locations observed for traits harbouring significant correlations and $29 \%$ of the co-locations detected between uncorrelated traits, probabilities were lower than 5\% suggesting that these observed co-locations are not due to chance alone.

\section{Co-locations between specific trait-QTLs and candidate} genes (CGs)

The probability that co-locations of QTLs and CGs occurred by chance was estimated considering all traits, all genes and all LGs for each parent. In E. urophylla, considering 94. QTLs and 40 CGs, the probability of 36 co-locations (involving $18 \mathrm{CGs}$ ) was $<10^{-4}$, indicating a non random association. For E. grandis, considering 33 QTLs and 34 CGs, the probability of 9 co-locations (involving $7 \mathrm{CGs}$ ) was 0.1791 , meaning these coincidences could not be considered as a non-random event.

In E. urophylla, out of the 18 CGs displaying such a coincidence (Table 4), five corresponded to known lignin biosynthetic genes (CCR, COMT, CAD2, CCoAOMT, $4 \mathrm{CL}$ ), two genes had a possible indirect effect on lignification (EgROP1 and SAH), 3 presented similarities with known function proteins (subtilisin-like proteinase, xyloglucan endo glycosylase, $60 \mathrm{~S}$ Ribosomal protein L7), while two corresponded to unknown proteins and 6 had no match in public databases. Co-locations of lignification genes were observed for different categories of traits indicating a possible genetic link between such traits and the lignification pathway: CCR co-located with one of the two QTLs detected for Klas on E. urophylla LG6. In the same linkage group, EgROP1 co-located with a QTL for S/G. COMT (LG7) and CAD2 (LG10) co-located with two QTLs for LGS 
Table 4 Co-locations between candidate genes and QTLs in E. urophylla and E. grandis

\begin{tabular}{|c|c|c|c|c|c|c|}
\hline \multirow[t]{2}{*}{ LG } & \multirow[t]{2}{*}{ Marker ID } & \multirow[t]{2}{*}{ Fonction } & \multicolumn{2}{|c|}{ E. urophylla } & \multicolumn{2}{|c|}{ E. grandis (NS) } \\
\hline & & & Trait-QTL & PEV (\%) & Trait-QTL & PEV (\%) \\
\hline \multirow[t]{3}{*}{1} & EST09F08 & unknown & $E_{30}$ & $8.4^{\mathrm{a}}$ & & \\
\hline & EST06D03 & 60 S Ribosomal protein L7 & $E_{30}$ & $8.4^{\mathrm{a}}$ & & \\
\hline & EST08E02 & unknown & & & FWL & 8.4 \\
\hline 2 & EST06D01 & unknown & Pil51; FWL; Fla; $\mu \mathrm{D}$ & $10.4 ; 12.8 ; 8.7 ; 9.9$ & Pil26 & 18.6 \\
\hline \multirow[t]{4}{*}{3} & EST08C02 & No hit & Pil14, Pil59, Klass & $6.7^{b} ; 12.8 ; 6.8$ & & \\
\hline & EST07H10 & No hit & Pil51 & 9.6 & & \\
\hline & EST06D09 & unknown & & & Pil51 & 7.6 \\
\hline & $\mathrm{SAH}$ & adenosylhomocysteinase & Pil14, Pil26, Pil38 & $6.7^{\mathrm{b}} ; 5.3 ; 5.7$ & & \\
\hline 5 & EST08C08 & No hit & Sld & 13.5 & Pil14, Pil26, FW & $7.6 ; 12.8 ; 11.1$ \\
\hline \multirow[t]{4}{*}{6} & $C C R$ & lignification & Klass & 14.7 & & \\
\hline & EST08E02 & Phytochelatin synthetase & & & Pil59 & 5.9 \\
\hline & EST08B02 & No hit & $F W, E_{30}, E_{2 i}$ & $7.1^{c} ; 11.6 ; 8.1$ & & \\
\hline & EgROP1 & Regulation & $F W, S / G$ & $7.1^{c} ; 37.0$ & & \\
\hline \multirow[t]{3}{*}{7} & COMT & lignification & $L G S, E_{30}, E_{2 i}$ & $5.2 ; 11.6 ; 14.5^{\mathrm{d}}$ & & \\
\hline & EST08H04 & unknown & & & Pil14 & 7.6 \\
\hline & EST09D03 & subtilisin-like proteinase & $E_{2 i}$ & $14.5^{\mathrm{d}}$ & & \\
\hline \multirow[t]{3}{*}{10} & CAD2 & lignification & LGS, Pil26 & $11.7 ; 24.5^{\mathrm{e}}$ & & \\
\hline & CCOAOMT & lignification & Pil26 & $24.5^{\mathrm{e}}$ & & \\
\hline & EST06C01 & no hit & SId & 4.1 & & \\
\hline \multirow[t]{2}{*}{11} & $4 \mathrm{CL}$ & lignification & Pil14, Pil38, Pil51, $\mu D, G, E_{30}, E_{2 i}$ & $25.4 ; 20.7 ; 16.4 ; 10.5 ; 13.0 ; 8.0 ; 4.5$ & & \\
\hline & EST07A07 & Xyloglucan endotransglycosylase & $S / G$ & 10.0 & $S / G$ & 6.8 \\
\hline
\end{tabular}

The PEV values are given for the corresponding QTLs.

a, b, c, d and e indicate that the same QTL co-localized with different candidate genes.

explaining $5.7 \%$ and $11.7 \%$ of the phenotypic variance respectively. Three lignification genes (CAD2, CCoAOMT and 4 CL) mapped on LG10 and LG11 and co-located with QTLs for Pil at different ages. Finally a co-location was found for LG11 between a putative xyloglucan endotransglycosylase (EST07A07) and a QTL for the S/G ratio not only in E. urophylla but also in $E$. grandis. Considering, the 7 structural genes of the lignification pathway mapped in E. urophylla (COMT, CCoAOMT, 4 CL, PAL C3H, CCR, CAD) and QTLs for lignin related traits (5 QTLs for S/G, 6 QTLs for Klas, 3 QTL for G, representing 12 independent QTL regions). The prior probability to obtain the two co-locations by chance alone was barely significant $(\mathrm{p}=0.0759)$.

\section{Discussion}

\section{Genetic architecture of wood properties-QTLs}

A total of 117 QTLs were detected for 26 WP-traits, i.e. an average of 4.5 QTLs per trait, which is consistent with the hypothesis that wood properties are under polygenic control. The difference in terms of detected QTLs in E. grandis and E. urophylla could be due to differences in level of heterozygosity between the two parents, as illustrated by the mapped codominant markers, heterozygosity being higher in E. urophylla (76\%) than in E. grandis (53\%). The mean number of QTLs varied according to the category of WP: Physical properties (Pyl and $\mu \mathrm{D}$ ) presented the highest number of QTLs (an average of 7 QTLs per trait) followed by mechanical (5.4 QTLs), chemical (3.7 QTLs), technological (2.3 QTLs) and anatomical (1.7 QTLs) properties. While most QTLs accounted for a rather low fraction of the phenotypic variation of WPs, 12 genomics regions (2 linked QTLs in each region) presented a PEV greater than 15\%. The L-shaped QTL distribution (Figure 4) obtained in the present study is consistent with other QTL studies involving similar sample size for low to medium heritability traits [65].

Thamarus et al. [24] published the first QTL study in Eucalyptus for a series of wood properties. These authors focused on three classes of WPs, namely chemical, density and fibre properties. They detected a total of 13 regions with an effect on density, chemical properties (cellulose content) and pulp and paper properties (pulp yield, fibre length and microfibrille angle) and some of them were found in two pedigrees of E. globulus, indicating a stable effect of these genomic regions. The detected effect explained from 3.2 to $15.75 \%$ of the phenotypic variance. In more recent investigations, Freeman et al. [26] detected 11 QTLs in E. globulus explaining between 5.6 to $12.3 \%$ of the phenotypic variation of WPs and Thumma et al. [27] detected 36 QTLs in E. 


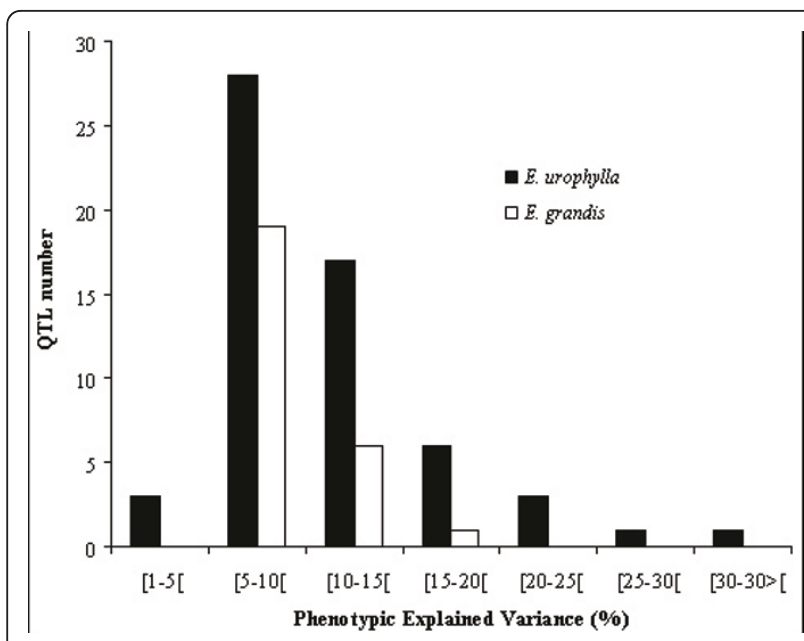

Figure 4 Distribution of effect classes for all wood property QTLs detected in E. urophylla and E. grandis.

nitens with minor effects $(<10 \%$ of the PEV). Even if large effect QTLs are biased upward because of the relative small population sizes used in most QTL studies [64], these results are encouraging for the characterization of the nature of QTLs with a major effect on wood properties using a map-based cloning approach. As more QTL studies accumulate, comparative QTL mapping will help to validate the presence of stable QTLs across the genus. We believe that such QTLs will be good targets for map-based cloning for a more fundamental aspect.

\section{Power of QTL detection}

For a given sample size of a given genetic background and for a given QTL detection method, the power of QTL detection depends on trait complexity, the extent of phenotypic variance of the trait, and the genetic parameters of the trait (heritability and the proportion of additive vs. non-additive variance).

Regarding trait complexity, chemical properties are likely to be less complex than integrated traits such as wood density or growth. Indeed, chemical properties often involve a single biosynthesis pathway consequently the number of QTLs is expected to be lower than for traits that are affected by many different physiological processes. The results of the present study agree with this hypothesis, the average number of QTLs being much higher for physical properties (7) than for chemical properties (3.7). Regarding the relationships between phenotypic variance and the number of QTLs, the following observations were made: i) the five traits with the highest CPV (>0.38) presented fewer QTLs (2.4 on average) than the traits with a lower $\operatorname{CPV}(<0.18,4.9$ QTLs on average). We attributed such high CPV for all technological (SId, SIw, SIm) and the two chemical (Fla and Poly) traits to a combined effect of intrinsic variability and environmental variations, including inaccuracy in trait measurement, ii) when considering only traits with a $\mathrm{CPV}<0.18$, we did not detect any relationship between the number of QTLs and the level of phenotypic variation. This result also held true when all the traits were taken into consideration (additional file 5 Figure S2). The same trends were reported by Thumma et al. [27], Thamarus et al. [24], and Freeman et al. [26] for a similar set of WPs in E. nitens and E. globulus. Therefore the extent of phenotypic variation apparently did not strongly influence the number of QTLs detected in our study.

In a full-sib progeny obtained from the control cross of highly heterozygous parents, analysis of marker-trait associations using dominant or co-dominant markers in a test-cross configuration (1:1 segregation), enables detection of QTLs for each parent of the cross and the null hypothesis tests an allelic substitution averaged over the alleles inherited from the other parent [20], i.e. an effect combining additivity and dominance. In such an experimental system, the power of QTL detection will not only depend on the level of narrow sense heritability of the trait [66] but will also be strongly affected by the extent of dominance. In our study, growth and chemical related traits presented a similar number of QTLs despite different levels of narrow sense heritabilities (additional file 6 - Table S4) and a different extent of additive variance [15]. We conclude that it remains impossible to predict the number of QTLs in a given context on the basis of trait variability and prior knowledge on genetic parameters.

\section{Co-locations between QTLs for correlated WPs suggests pleiotropic effect rather than physical linkage}

We tested whether QTLs collocate assuming the null hypothesis that they are randomly and independently distributed. Overall, we rejected the null hypothesis in $52 \%$ of the case but this ratio was much higher for correlated traits (65\%) than for uncorrelated traits (25\%), suggesting as expected that correlated traits shared more often spatial position of QTLs than in the case of uncorrelated traits.

Two classical hypotheses can be proposed to explain significant co-locating QTLs: Pleiotropy (i.e. several traits controlled by a single gene) $v s$. physical linkage (i. e. cluster of genes controlling different traits). In respect to correlated traits, the fact that 79 significant co-locations (most occurring several times in different regions) with similar allelic effects between different WPs were identified, suggests a common molecular basis for the genetic control of these correlated traits. Indeed, if a single co-location of 2 QTLs could be due to chance alone, the observation of multiple co-locations could be 
considered as a good indication of a common genetic control of the different WPs, reflecting the effects of pleiotropic genes rather than the presence of several linked genes. This was particularly clear for wood density measured at different maturation stages (from age 14 to 59 months), showing multiple occurrences of Pil QTLs. This result also suggests that the genetic control of wood density is quite stable during ontogenic development. The presence of stable QTLs for wood density is further supported by the presence of co-locating QTLs for $\mu \mathrm{D}$ (an integrated measurement of wood density across the whole tree ring) in the three distinct chromosomal regions harbouring QTLs for Pil (i.e. in LG2, 4 and 11). Co-located QTLs for non-correlated traits were less frequent and usually involved a single chromosomal region. In this case, "linked genes" is a more likely hypothesis and such coincidences simply result from the strong linkage disequilibrium (LD) between distant loci in the mapping pedigree. In the coming years, fine QTL mapping [67] combined with knowledge of the Eucalyptus genome sequence [http:// web.up.ac.za/eucagen] should improve our understanding of the nature of the detected QTLs and disentangle pleiotropy versus physical linkage.

The presence of QTLs in orthologous regions validate the presence of generic genomic regions for WPs

Homologous LGs between the male (E. grandis) and female (E. urophylla) maps were identified using codominant markers. A total of nine orthologous regions (representing $31 \%$ and $35 \%$ of the total length of E. urophylla and E. grandis genetic maps, respectively) were identified based on multiple parallel linkages of orthologous markers, making it possible to identify similar genomic regions controlling WPs. Hot spots of QTLs found in both species were thus identified on LG5, LG6, LG7 and LG11 (Figures 2 and 3). Thumma et al. [27] also reported co-location of QTLs for fibre properties in $E$. nitens and for wood density in E. globulus for two orthologous QTL regions. In this paper, we were able to identify several orthologous regions with the same traitQTLs between E. urophylla and E. grandis (e.g. for Pil51 in LG3 and for S/G ratio in LG6 and LG11) which is a good indication of the reliability of the detected QTLS.

Comparing our study with that of Thumma et al. [27], two orthologous regions between E. urophylla, E. grandis, E. nitens and E. globulus were identified harbouring WP-QTLs: i) wood density QTLs in the region surrounding microsatellite marker EMBRA15 mapped on LG3 in E. urophylla and E. grandis, and on LG8 in E. nitens and E. globulus, and ii) chemical and MFA QTLs around the CCR gene mapped on LG6 in E. urophylla and E. grandis and LG10 in E. nitens and E. globulus. A table of correspondence between LGs of this study and that of Brondani et al. [50] based on SSR markers is available in additional file 7 - Table S5. The clustering of WP-QTLs in orthologous genomic regions in different species indicates that these regions could be of general interest for the Eucalyptus genus and should be considered as important targets for QTL dissection. The presence of stable regions for WPs across species is also coherent with results of quantitative genetic analyses which generally indicate that WPs present higher narrow sense heritability than growth related traits (reviewed by Raymond [4]). Even if heritability varies between WPs and depends to a great extent on the genetic context and environmental conditions of the trials, most results (reviewed in Additional file 6 - Table S4 for Eucalyptus species) agree with a medium to strong genetic control for WPs.

\section{Decoding the genes underlying QTLs}

In our study, we detected co-locations between expressional (e.g. transcripts over-expressed in differentiating xylem as compared to other tissues, [68]) or functional (i.e. genes of known function) candidate genes and QTLs for physical and chemical properties in E. urophylla and E. grandis. Although we are aware that many genes are possibly involved, because of the large QTL confidence intervals (several cM), we believe that some co-locations would merit further investigations because they are supported by additional sources of evidence from reverse and forward genetics experiments or functional genomics (transcriptomics, proteomics) studies.

The most notable co-location was found in E. urophylla (LG6) of a gene encoding a structural gene of the lignification pathway (CCR) and a QTL for lignin content (Klas). Associations between CCR and WPs have been already reported in Eucalyptus. Thamarus et al. [24] and Thumma et al. [27] reported co-locations of CCR and QTLs for pulp yield and cellulose content (in E. globulus) and MFA (in E. nitens) respectively. Using an association genetics approach, Thumma et al. [69] and Mandrou et al. [A candidate gene for lignin composition in Eucalyptus, submitted] detected effects of nucleotide variability in CCR on MFA (in E. nitens) and S/G ratio (in E. urophylla), respectively. The existence of a single CCR gene in Eucalyptus [70,71] reinforces the hypothesis of a single orthologous region surrounding CCR with an effect on several WPs across different genetic backgrounds. The association between CCR, or surrounding gene polymorphisms in LD with CCR, and a series of uncorrelated WPs in different species, suggests the presence of a gene cluster controlling different wood properties in this chromosomal region. As soon as the genome sequence of several Eucalyptus species is available, regional association mapping with marker saturation around the CCR locus will enable more 
precise characterization of the polymorphisms involved in variations of wood property. Other lignification genes (4 CL, COMT, CAD2 and CCoAOMT) co-located with mechanical (LGS, E) and technological (SI) wood properties in E. urophylla (LG7, LG10, LG11), which is coherent with the high correlations observed between wood chemistry (especially lignin content and composition) and ultrastructural properties (LGS, MFA) [3,72]. Co-location of lignification genes $(4 \mathrm{CL}, \mathrm{C} 3 \mathrm{H}, \mathrm{C} 4 \mathrm{H}$ and CCoAOMT) and WP (wood specific gravity) was also observed by Brown et al. [73] in Pinus taeda.

Another noteworthy co-location concerns EgROP1 (a member of the plant ROP family of Rho-like GTPases) and a QTL for S/G ratio in E. urophylla (LG6). Using a transgenesis approach in Arabidopsis thaliana, Fourcart et al. [32] found that plants overexpressing this gene exhibited larger vessel-like cells containing $G$ units and hypothesized that this signaling protein might affect lignin composition by influencing the vessel to fibre ratio. Using an association mapping approach, Mandrou et al. [A candidate gene for lignin composition in Eucalyptus, submitted] also found that a SNP in this gene was associated with the $S / G$ ratio, providing an additional line of evidence of the importance of this regulatory gene in controlling lignin quality.

\section{Conclusion}

This report constitutes the most extensive contribution (in terms of number of traits analyzed) to the understanding of the genetic architecture of wood properties in the most planted tree species worldwide, and opens great perspectives to decipher the nature of the underlying genes, the eucalyptus genome being now available (http://www.phytozome.net/eucalyptus.php). Several genomic regions with major effects were detected for all the studied traits. The co-location between QTLs for different WP categories, suggests the existence of generic genomic regions corresponding to clusters of genes with independent effects on different WPs or genes with pleiotropic effects. Some co-locations between known function genes (e.g. CCR) and WP QTLs (e.g. lignin content) agrees with previous results using forward or reverse genetic approaches, and contribute to increase our knowledge about the nature of quantitative trait loci controlling wood quality.

\section{Additional material}

Additional file 1: Table S1: Linkage group location of codominant markers (EST, SSR and STS) on E. urophylla and E. grandis linkage maps based on their segregation in the interspecific F1 progeny.

Additional file 2: Table S2: Characteristics of E. urophylla and E. grandis genetic maps. The total length (in $\mathrm{CM}$ ) of each linkage group (LG) was obtained using the Kosambi function. The total number of framework markers (Fr markers) and codominant markers (Co markers) are provided.
Additional file 3: Figure S1: Distribution of WP and growth QTLS on the linkage groups of E. urophylla and E. grandis.

Additional file 4: Table S3: Probability of a random co-location of QTL pairs in E. urophylla (E.U) and E. grandis (E.g).

Additional file 5: Figure S2: Number of detected QTLS as a function of the coefficient of phenotypic variation (CPV) for all the traits.

Additional file 6: Table S4: Literature review of estimated heritability for wood properties and growth in Eucalyptus species.

Additional file 7: Table S5: Correspondences between linkage groups (LGS) of this study and that of Brondani et al. [50] based on SSR markers.

\section{Acknowledgements and funding}

We acknowledge support from the Ministère de l'Enseignement de la Recherche et de la Technologie (procédure Biotechnologie décision no. 98C0204). This project was also partially supported by CIRAD, the Aquitaine region (FEDER, $n^{\circ}$ presage: 32973 ) and ANR under the ERANET programme "EUCANET" (ERA-PG 054B EUCANET). We thank the students, researchers and breeders for continuous discussions and scientific inputs. Special thanks are due to the staff of the CRDPI research unit in the Republic of Congo.

\section{Author details}

${ }^{1}$ CIRAD, Department of Biological System, Research Unit "Genetic improvement and adaptation of mediterranean and tropical plants" TA A108/C, Campus International de Baillarguet, 34398 Montpellier Cedex, France. ${ }^{2}$ USBB - Institut du Pin, 351 cours de la libération, 33405 TALENCE Cedex, France. ${ }^{3}$ INRA, Unité d'Amélioration, Génétique et Physiologie Forestières, Olivet 45166, France. ${ }^{4}$ CIRAD, Department of Tropical Production system and Process Performance, Research Unit "Processing and promotion of Tropical Woods" 73 rue J-F Breton - TA B-40/16 - 34398 Montpellier Cedex 5, France. ${ }^{5}$ RAIZ - Forestry \& Paper Research Institute, Qta S. Francisco, Apartado 15, Eixo, 3801-501 Aveiro, Portugal. ${ }^{6}$ CRDPI, BP 1291, Pointe Noire, République du Congo. ${ }^{7}$ UMR UPS/CNRS 5546, Pôle de Biotechnologies Végétales, 24 chemin de Borde Rouge, BP42617, Auzeville Tolosane, 31326 Castanet Tolosan, France. ${ }^{8}$ INRA, UMR 1202 BIOGECO, 69 route d'Arcachon, 33612 Cestas Cedex, France.

\section{Authors' contributions}

JMG, AC, SD, CB, FB: Genotyping and genetic mapping analysis; JMG, FP, $J P C, H B, P R, N O$ : wood properties phenotyping; JMG, VC: primer design for EST markers; JMG: QTL analysis; JMG, CP: manuscript preparation; JMG, DV, JGP, PV, CP: project design, funding and overall supervision. All authors have read and approved the final manuscript

Received: 10 February 2011 Accepted: 8 June 2011

Published: 8 June 2011

\section{References}

1. FAO: State of the World's Forests 2007. Food and Agriculture Organization of the United Nations. Rome. 2007 [http://www.fao.org/ docrep/009/a0773e/a0773e00.HTM].

2. Grattapaglia D, Plomion C, Kirst M, Sederoff R: Genomics of growth traits in forest trees. Current opinion in plant biology 2009, 12:148-56.

3. Plomion C, LeProvost G, Stokes A: Wood formation in trees. Plant Physiol 2001, 127:1513-1523.

4. Raymond CA: Genetics of Eucalyptus wood properties. Ann For Sci 2002, 59:525-531.

5. Malan FS, Gerischer GFR: Wood property differences in South African grown Eucalyptus grandis trees of different growth stress intensity. Holzforschung 1987, 41:331-335.

6. Muneri A, Leggate W, Palmer G: Relationships between surface growth strain and some tree, wood and sawn timber characteristics of Eucalyptus cloeziana trees. Southern Afri For 1999, 186:41-49.

7. Yang JL, Fife D, Waugh $G$, Downes $G$, Blackwell P: The effect of growth strain and other defects on the sawn timber quality of 10-year-old Eucalyptus globulus Labill. Aust For 2002, 65:31-37.

8. Baillères $\mathrm{H}$, Vitrac $\mathrm{O}$, Ramananantoandro $\mathrm{T}$ : Assessment of continuous distribution of wood properties from a low number of samples: 
application to the variability of modulus of elasticity between trees and within tree. Holzforschung 2005, 59:524-530.

9. Trugilho PF, Rosado SCD, Lima JT, de Padua FA, de Souza MAM: Longitudinal residual strain (DRL) and its relationship with the characteristics of the tree growth in Eucalyptus clones. Cerne 2009, 13:130-137.

10. Biechele T, Nutto L, Becker G: Growth Strain in Eucalyptus nitens at Different Stages of Development. Silva Fennica 2009, 43:669-679.

11. dos Santos PET, Geraldi IO, Garcia JN: Estimates of genetic parameters of wood traits for sawn timber production in Eucalyptus grandis. Genet Mol Biol 2004, 27:567-573.

12. Kien ND, Quang TH, Jansson G, Harwood C, Clapham D, Arnold S: Cellulose content as a selection trait in breeding for kraft pulp yield in Eucalyptus urophylla. Ann For Sci 2009, 66:7111-7118.

13. Santos A, Amaral ME, Vaz A, Anjos O, Simoes R: Effect of Eucalyptus globulus wood density on papermaking potential. Tappi Journal 2008, 7:25-32.

14. Matsushita $Y$, Kurono $Y$, Suzuki A, Imai T, Yasuda S, Xie YM: Effect of chemical composition and wood properties on kraft pulping of eucalyptus - Difference in soluble and insoluble wood extractives between Eucalyptus viminalis and Eucalyptus globulus. Conference Information: 2nd International Symposium on Emerging Technologies of Pulping and Papermaking Guangzhou, Peoples R China, oct 09-11, 2002

15. Apiolaza LA, Raymond CA, Yeo BJ: Genetic variation of physical and chemical wood properties of Eucalyptus globulus. Silvae Genet 2005, 54:160-166.

16. Harrand L, Hernandez JJV, Upton JL, Valverde GR: Genetic parameters of growth traits and wood density in Eucalyptus grandis progenies planted in Argentina. Silvae Genet 2009, 58:11-19.

17. Silva JCE, Borralho NMG, Araujo JA, Vaillancourt RE, Potts BM: Genetic parameters for growth, wood density and pulp yield in Eucalyptus globulus. Tree Genetics \& Genomes 2009, 5:291-305.

18. Grattapaglia D: Perspectives on genome mapping and marker-assisted breeding of eucalypts. Southern Forests: a Journal of Forest Science 2008, 71:69-75.

19. Doerge RW: Mapping and analysis of quantitative trait loci in experimental populations. Nature Reviews Genetics 2002, 3:43-52.

20. Grattapaglia D, Bertolucci FLG, Penchel R, Sederoff RR: Genetic mapping of quantitative trait loci controlling growth and wood quality traits in Eucalyptus grandis using a maternal half-sib family and RAPD markers. Genetics 1996, 144:1205-1214.

21. Verhaegen D, Plomion C, Gion JM, Poitel M, Costa P, Kremer A: Quantitative trait dissection analysis in Eucalyptus using RAPD markers: 1. Detection of QTL in interspecific hybrid progeny, stability of QTL expression across different ages. Theor Appl Genet 1997, 95:597-608.

22. Bundock PC, Potts BM, Vaillencourt R: Detection and stability of quantitative trait loci (QTL) in Eucalyptus globulus. Tree Genetics \& Genomes 2008, 4:85-95

23. Barros $E$, Verryn $S$, Hettasch $M$ : Identification of PCR-base markers linked to wood splitting in Eucalyptus grandis. Ann For Sci 2002, 59:675-678.

24. Thamarus KA, Groom K, Bradley AD, Raymond CA, Moran GF: Identification of quantitative trait loci for wood and fibre properties in two full sib pedigrees of Eucalyptus globulus. Theor Appl Genet 2004, 109:856-864.

25. Rocha RB, Barros EG, Cruz CD, Rosado AM, Araujo EF: Mapping of QTLs related with wood quality and developmental characteristics in hybrids (Eucalyptus grandis * Eucalyptus urophylla). Revista Arvore 2007, 31:13-24.

26. Freeman JS, Whittock SP, Potts BM, Vaillancourt RE: QTL influencing growth and wood properties in Eucalyptus globulus. Tree Genetics and Genomes 2009, 5:713-722.

27. Thumma BR, Southerton SG, Bell JC, Owen JV, Henery ML, Moran GF: Quantitative trait locus (QTL) analysis of wood quality traits in Eucalyptus nitens. Tree Genetics \& Genomes 2010, 6:305-317.

28. Myburg AA, Potts BM, Marques CMP, Kirst M, Gion J-M, Grattapaglia D, Grima-Pettenati J: Eucalyptus. In Genome Mapping \& Molecular Breeding in Plants. Volume 7. Edited by: Kole CR. Forest Trees. Springer, Heidelberg; 2007.

29. Paux E, Tamasloukht M, Ladouce N, Sivadon P, Grima-Pettenati J: Identification of genes preferentially expressed during wood formation in Eucalyptus. Plant Mol Biol 2004, 55:263-280.

30. Novaes E, Drost DR, Farmerie WG, Pappas GJ Jr, Grattapaglia D, Sederoff RR, Kirst M: High-throughput gene and SNP discovery in Eucalyptus grandis, an uncharacterized genome. BMC Genomics 2008, 9:312.
31. Goicoechea M, Lacombe E, Legay $S$, Mihaljevic $S$, Rech P, Jauneau A, Lapierre C, Pollet B, Verhaegen D, Chaubet-Gigot N, Grima-Pettenati J: EgMYB2, a new transcriptional activator from Eucalyptus xylem, regulates secondary cell wall formation and lignin biosynthesis. Plant $J$ 2005, 43:553-567.

32. Foucart C, Jauneau A, Gion JM, Amelot N, Martinez Y, Panegos P, GrimaPettenati J, Sivadon P: Overexpression of EgROP1, a Eucalyptus vascularexpressed Rac-like small GTPase, affects secondary xylem formation in Arabidopsis thaliana. New Phytol 2009, 183:1014-1029.

33. Verhaegen D, Plomion C: Genetic mapping in Eucalyptus urophylla and E. grandis using RAPD markers. Genome 1996, 39:1051-1061.

34. Gion JM, Rech P, Grima Pettenati J, Verhaegen D, Plomion C: Mapping candidate genes in Eucalyptus with emphasis on lignification genes. Mol Breed 2000, 6:441-449.

35. Doyle JJ, Doyle JL: Isolation of DNA from fresh plant tissue. Focus 1990, 12:13-15.

36. Effland M: Modified procedure to determine acid insoluble lignin in wood and pulp. Tappi 1977, 60:143-144.

37. Rolando C, Monties B, Lapierre C: Methods in lignin chemistry. In Chapter 6.4: Thioacidolysis pp 334-350. Springer Series in Wood. Edited by: Stephen Y Lin, Carlton W Dence. Timell, Springer-Verlag; 1992:578.

38. Singleton VL, Rossi JA Jr: Colorimetry of total phenolics with phosphomolybdic-phosphotungstic acid reagents. A J Enol Vitic 1965, 16:144-158.

39. Boizot N, Charpentier JP: Méthode rapide d'évaluation du contenu en composés phénoliques des organes d'un arbre forestier. Le Cahier des Techniques de I'INRA, Numéro spécial 2006: Méthodes et outils pour l'observation et l'évaluation des milieux forestiers, prairiaux et aquatiques 2006, 79-82.

40. Treutter D: Chemical reaction detection of catechins and proanthocyanidins with 4-dimethylaminocinnamaldehyde. J Chrom 1989, 467:185-193.

41. Fournier M, Chanson B, Thibaut B, Guitard D: Measurement of residual growth strains at the stem surface. Observations of different species. Ann For Sci 1994, 51:249-266.

42. Brancheriau L, Baillères H: Natural vibration analysis of clear wooden beams: a theoretical review. Wood Science and Technology 2002, 36:347-365.

43. Polge H: Fifteen years of wood radiation densitometry. Wood Science and Technology 1978, 12:187-196.

44. Mothe F, Duchanois G, Zannier B, Leban JM: Microdensitometric analysis of wood samples: data computation method used at INRA-ERQB (CERD programme). Ann For Sci 1998, 55:301-313.

45. Nehls U, Beguiristain T, Ditengou F, Lapeyrie F, Martin F: The expression of a symbiosis-regulated gene in eucalypt roots is regulated by auxins and hypaphorine, the tryptophan betaine of the ectomycorrhizal basidiomycete Pisolithus tinctorius. Planta 1998, 207:296-302.

46. Carnero Diaz M, Martin F, Tagu D: Eucalypt alpha-tubulin: CDNA cloning and increased level of transcripts in ectomycorrhizal root system. Plant Mol Biol 1996, 31:905-910.

47. Dornelas MC, Amaral WAN do, Rodriguez APM: EgLFY, the Eucalyptus grandis homolog of the Arabidopsis gene LEAFY is expressed in reproductive and vegetative tissues. Plant Cell Tissue and organ culture 2004, 79:53-61

48. Southerton SG, Strauss SH, Olive MR, Harcourt RL, Decroocq V, Zhu X, Llewellyn DJ, Peacock WJ, Dennis ES: Eucalyptus has a functional equivalent of the Arabidopsis floral meristem identity gene LEAFY. Plant Mol Biol 1998, 37:897-910.

49. Kirst M, Myburg AA, De León JPG, Kirst ME, Scott J, Sederoff R: Coordinated Genetic Regulation of Growth and Lignin Revealed by Quantitative Trait Locus Analysis of CDNA Microarray Data in an Interspecific Backcross of Eucalyptus. Plant Physiol 2004, 135:2368-2378.

50. Brondani RPV, Brondani C, Tarchini R, Grattapaglia D: Development, characterisation and mapping of microsatellite markers in Eucalyptus grandis and E. urophylla. Theor Appl Genet 1998, 97:816-827.

51. Orita M, Iwahana H, Kanazawa H, Hayashi K, Sekiya T: Detection of polymorphisms of human DNA by gel electrophoresis as single-strand conformation polymorphisms. Proc Natl acad Sci USA 1989, 86:2766-2770.

52. Mariette S, Cottrell J, Csaikl U, Goikoechea P, König A, Lowe A, Van Dam B, Barreneche T, Bodénès C, Streiff R, Burg K, Groppe K, Munro R, Tabbener H, and Kremer $\mathrm{A}$ : Comparison of levels of genetic diversity detected with 
AFLP and microsatellite markers within and among mixed Q. petraea (Matt.) Liebl. and Q. robur L. stands. Silvae Genet 2002, 51:72-79.

53. Grattapaglia D, Sederoff R: Genetic linkage maps of Eucalyptus grandis and E. urophylla using a pseudo-testcross mapping strategy and RAPD markers. Genetics 1994, 37:1121-1137.

54. Lander ES, Green P, Abrahamson J, Barlow A, Daly MJ, Lincoln SE, Newburg L: MAPMAKER: an interactive computer package for constructing primary genetic linkage maps of experimental and natura populations. Genomics 1987, 1:174-181.

55. Jansen RC, Stam P: High resolution of quantitative traits into multiple loci via interval mapping. Genetics 1994, 136:1447-1455.

56. Doerge RW, Churchill GA: Permutation tests for multiple loci affecting a quantitative character. Genetics 1996, 142:285-294.

57. Scotti-Saintagne $C$, Bodénès $C$, Barreneche $T$, Bertocchi E, Plomion C, Kremer A: Detection of quantitative trait loci controlling bud burst and height growth in Quercus robur L. Theor Appl Genet 2004, 109:1648-1659.

58. Parelle J, Zapater M, Scotti-Saintagne C, Kremer A, Jolivet Y, Dreyer E, Brendel O: Quantitative Trait Loci of tolerance to water-logging in a European oak (Quercus robur L.): physiological relevance and temporal QTL effect patterns. Plant Cell Environ 2007, 30:422-434.

59. Pot D, Rodrigues JC, Rozenberg P, Chantre G, Tibbits J, Cahalan C Pichavant F, Plomion C: QTLs and candidate genes for wood properties in maritime pine (Pinus pinaster Ait.). Tree Genetics \& Genome 2006 2:10-24.

60. Visscher PM, Thompson R, Haley CS: Confidence intervals in QTL mapping by bootstrapping. Genetics 1996, 143:1013-1020.

61. Voorrips RE: MapChart: Software for the graphical presentation of linkage maps and QTLs. J Hered 2002, 93:77-78.

62. Lin YR, Shertz KF, Paterson AH: Comparative analysis of QTLs affecting plant height and maturity across the Poaceae, in reference to an interspecific Sorghum population. Genetics 1995, 141:391-411.

63. Rencoret J, Marques G, Gutierrez A, Ibarra D, Li J, Gellerstedt G, Santos JI, Jimenez-Barbero J, Martinez AT, del Rio JC: Structural characterization of milled wood lignins from different eucalypt species. Holzforschung 2008 62:514-526.

64. Beavis WD: The power and deceit of QTL experiments: Lessons from comparative QTL studies. Proceedings of the Forty-ninth Annual Corn and Sorghum Industry Research Conference, ASTA, Washington DC 1994, 250-266.

65. Bost B, de Vienne D, Hospital F, Moreau L, Dillmann C: Genetic and Nongenetic Bases for the L-Shaped Distribution of Quantitative Trait Loci Effects. Genetics 2001, 157:1773-1787.

66. Kaeppler SM: Power analysis for quantitative trait locus mapping in populations derived by multiple backcrosses. Theor Appl Genet 1997 95:618-621.

67. Salvi S, Tuberosa R: To clone or not to clone plant QTLs: present and future challenges. TRENDS in Plant Science 2005, 10:297-304.

68. Paux E, Carocha V, Marques C, Mendes de Sousa A, Borralho N, Sivadon P, Grima-Pettenati J: Transcript profiling of Eucalyptus xylem genes during tension wood formation. New Phytol 2005, 167:89-100.

69. Thumma BR, Nolan MF, Evans R, Moran GF: Polymorphisms in Cinnamoyl CoA Reductase (CCR) are associated with variation in microfibril angle in Eucalyptus spp. Genetics 2005, 171:1257-1265.

70. Poke FS, Vaillancourt RE, Elliott RC, Reid JB: Sequence variation in two lignin biosynthesis genes, cinnamoyl CoA reductase (CCR) and cinnamyl alcohol dehydrogenase 2 (CAD2). Mol Breed 2003, 12:107-118.

71. Lacombe E, Hawkins S, Van Doorsselaere J, Piquemal J, Goffner D, Poeydomenge O, Boudet AM, Grima-Pettenati J: Cinnamoyl CoA reductase, the first commited enzyme of the lignin branch biosynthetic pathway: cloning, expression and phylogenetic relationships. The Plant Journal 1997, 11:429-441.

72. Bailleres H, Chanson B, Fournier M, Tollier MT, Monties B: Structure, composition chimique et retraits de maturation du bois chez des clones d'Eucalyptus. Ann For Sci 1995, 52:157-172.

73. Brown GR, Bassoni DL, Gill GP, Fontana JR, Wheeler NC, Megraw RA, Davis MF, Sewell MM, Tuskan GA, Neale DB: Identification of quantitative trait loci influencing wood property traits in loblolly pine III QTL verification and candidate gene mapping. Genetics 2003, 164:1537-1546.

doi:10.1186/1471-2164-12-301

Cite this article as: Gion et al: Comprehensive genetic dissection of wood properties in a widely-grown tropical tree: Eucalyptus. BMC Genomics 2011 12:301.

\section{Submit your next manuscript to BioMed Central and take full advantage of:}

- Convenient online submission

- Thorough peer review

- No space constraints or color figure charges

- Immediate publication on acceptance

- Inclusion in PubMed, CAS, Scopus and Google Scholar

- Research which is freely available for redistribution

Submit your manuscript at www.biomedcentral.com/submit
Biomed Central 